Article

\title{
Synthesis and Biological Evaluation of New Pyridothienopyrimidine Derivatives as Antibacterial Agents and Escherichia coli Topoisomerase II Inhibitors
}

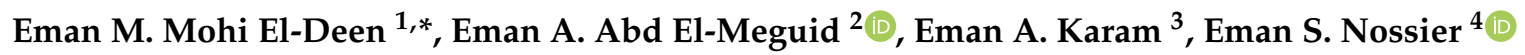 \\ and Marwa F. Ahmed 5,6 \\ 1 Department of Therapeutic Chemistry, National Research Centre, Dokki, Cairo 12622, Egypt \\ 2 Department of Chemistry of Natural and Microbial Products, National Research Centre, Dokki, \\ Cairo 12622, Egypt; ea.mabrouk@nrc.sci.eg \\ 3 Microbial Chemistry Department, National Research Centre, Dokki, Cairo 12622, Egypt; \\ em.karam@nrc.sci.eg \\ 4 Department of Pharmaceutical Medicinal Chemistry, Faculty of Pharmacy (Girls), Al-Azhar University, \\ Cairo 11754, Egypt; dremannossier@azhar.edu.eg \\ 5 Department of Pharmaceutical Chemistry, Faculty of Pharmacy, Taif University, Taif 21974, Saudi Arabia; \\ Marwa_farag@pharm.helwan.edu.eg \\ 6 Department of Pharmaceutical Chemistry, Faculty of Pharmacy, Helwan University, Cairo 11795, Egypt \\ * Correspondence: em.mohi@nrc.sci.eg; Tel.: +20-0106-385-3338
}

Received: 2 September 2020; Accepted: 7 October 2020; Published: 14 October 2020

\begin{abstract}
The growing resistance of bacteria to many antibiotics that have been in use for several decades has generated the need to discover new antibacterial agents with structural features qualifying them to overcome the resistance mechanisms. Thus, novel pyridothienopyrimidine derivatives $(\mathbf{2} \mathbf{a}, \mathbf{b}-\mathbf{a}, \mathbf{b})$ were synthesized by a series of various reactions, starting with 3 -aminothieno [2,3-b]pyridine-2-carboxamides $(\mathbf{1} \mathbf{a}, \mathbf{b})$. Condensation of compounds $\mathbf{1} \mathbf{a}, \mathbf{b}$ with cyclohexanone gave $1^{\prime} H$-spiro[cyclohexane-1,2'-pyrido[ $\left[3^{\prime}, 2^{\prime}: 4,5\right]$ thieno[3,2-d]pyrimidin]-4' $\left(3^{\prime} H\right)$-ones $(\mathbf{2 a}, \mathbf{b})$, which in turn were utilized to afford the target 4 -substituted derivatives $(\mathbf{3} \mathbf{a}, \mathbf{b}-\mathbf{8} \mathbf{a}, \mathbf{b})$. In vitro antibacterial activity evaluations of all the new compounds $(\mathbf{2} \mathbf{a}, \mathbf{b}-\mathbf{8} \mathbf{a}, \mathbf{b})$ were performed against six strains of Gram-negative and Gram-positive bacteria. The target compounds showed significant antibacterial activity, especially against Gram-negative strains. Moreover, the compounds $(\mathbf{2} \mathbf{a}, \mathbf{b} ; \mathbf{3} \mathbf{a}, \mathbf{b} ; \mathbf{4} \mathbf{a}, \mathbf{b} ;$ and $\mathbf{5 a}, \mathbf{b})$ that exhibited potent activity against Escherichia coli were selected to screen their inhibitory activity against Escherichia coli topoisomerase II (DNA gyrase and topoisomerase IV) enzymes. Compounds 4a and $4 \mathrm{~b}$ showed potent dual inhibition of the two enzymes with $\mathrm{IC}_{50}$ values of $3.44 \mu \mathrm{M}$ and $5.77 \mu \mathrm{M}$ against DNA gyrase and $14.46 \mu \mathrm{M}$ and $14.89 \mu \mathrm{M}$ against topoisomerase IV, respectively. In addition, docking studies were carried out to give insight into the binding mode of the tested compounds within the E. coli DNA gyrase B active site compared with novobiocin.
\end{abstract}

Keywords: pyridothienopyrimidines; antibacterial activity; enzyme inhibition; DNA gyrase; topoisomerase IV; molecular docking

\section{Introduction}

Nowadays, the danger of infectious diseases is again on the rise because of the persistent evolution of antibiotic resistance, which will, over time, be a significant threat to health worldwide [1,2].

Antimicrobial-resistant infections are predicted to cause millions of deaths in the coming decades, unless suitable actions are taken to overcome this risk [3]. Thus, there is an urgent need to discover 
new classes of antimicrobial agents with novel mechanisms of action that can circumvent the resistance problem [4]. Inhibition of bacterial DNA replication enzymes is considered a promising strategy for fighting antimicrobial resistance [5]. Among these enzymes are two bacterial type II topoisomerases, DNA gyrase and topoisomerase IV, which play a significant role in bacterial cell cycle progression [6]. Although the two enzymes have similar structures, each of them has a distinct function during DNA replication: DNA gyrase remains unique in its role to introduce negative supercoiling into DNA, while the critical function of topoisomerase IV is to decatenate daughter chromosomes following DNA replication $[6,7]$.

In clinical use, there are two main classes of antibiotics that target topoisomerase II enzymes, the first is the aminocoumarins class and the second is the quinolones class [8]. Aminocoumarins, such as novobiocin and clorobiocin, inhibit the ATPase domain of the enzymes [9], but their manufacturing and clinical usage have been limited due to their poor pharmacological properties and mammalian cytotoxicity [10]. While, quinolone antibiotics, such as ciprofloxacin and norfloxacin, inhibit topoisomerase II enzymes by binding to a DNA-enzyme complex that leads to stabilizing the DNA double-strand breaks and causes rapid death of the bacterial cell [11,12]. However, after decades of using quinolones in treating a variety of bacterial infections, the number of bacterial strains resistant to this important class of antimicrobial agents has seen an unremitting increase [13]. The most prevalent quinolone-resistance mechanism is associated with specific mutations in the DNA gyrase and/or topoisomerase IV enzymes that reduce the drug's binding ability to the enzyme-DNA complex, resulting in significant weakness in the quinolone's therapeutic activity [11,14]. Therefore, some recent efforts to counter microbial resistance mechanisms have included design and synthesis of non-quinolone-based inhibitors able to target varied active sites in bacterial type II topoisomerases and exhibit more potent antimicrobial activity [15-18].

On the other hand, many reports have documented the important biological activities of thieno[2,3-b]pyridine derivatives in anticancer [19-21], antimicrobial [22,23], antiviral [24,25], anti-inflammatory [26] and osteogenic [27] activities. As a result, thieno[2,3-b]pyridine compounds and their fused derivatives with the bioactive pyrimidine ring [28,29] have attracted great interest in the last decade; several pyrido[3',2':4,5]thieno[3,2- $d]$ pyrimidine derivatives were synthesized and gave significant pharmacological properties as antimicrobial [30-32], anticancer [33,34] and protein kinase inhibitors [35,36]. Moreover, some thieno[2,3- $b$ ]pyridine derivatives [37] and pyrimidine-based compounds $[38,39]$ have been discovered in recent years as potent DNA gyrase and/or topoisomerase IV inhibitors, which encourage the design and synthesis of novel thienopyridine-fused pyrimidine compounds to obtain enhanced antibacterial activity (Figure 1).

Based on the above, the current work includes the synthesis of a series of $1^{\prime} H$-spiro[cyclohexane$1,2^{\prime}$-pyrido[3',2':4,5]thieno[3,2-d]pyrimidine] derivatives as new antibacterial agents. The target compounds were linked at position 4 of the pyridothienopyrimidine ring system to different moieties, such as piperazine, morpholine, acetohydrazide and aryl hydrazone, which have valuable pharmacological activities [40-43]. All the new compounds were screened for their antibacterial activity against different Gram-positive and Gram-negative bacterial strains. Then, the most active compounds against Gram-negative bacteria were tested for their inhibitory activity of Escherichia coli DNA gyrase and topoisomerase IV enzymes. Molecular docking studies were also performed for elucidation of the mode of binding of these compounds in the active site of DNA gyrase B kinase. 


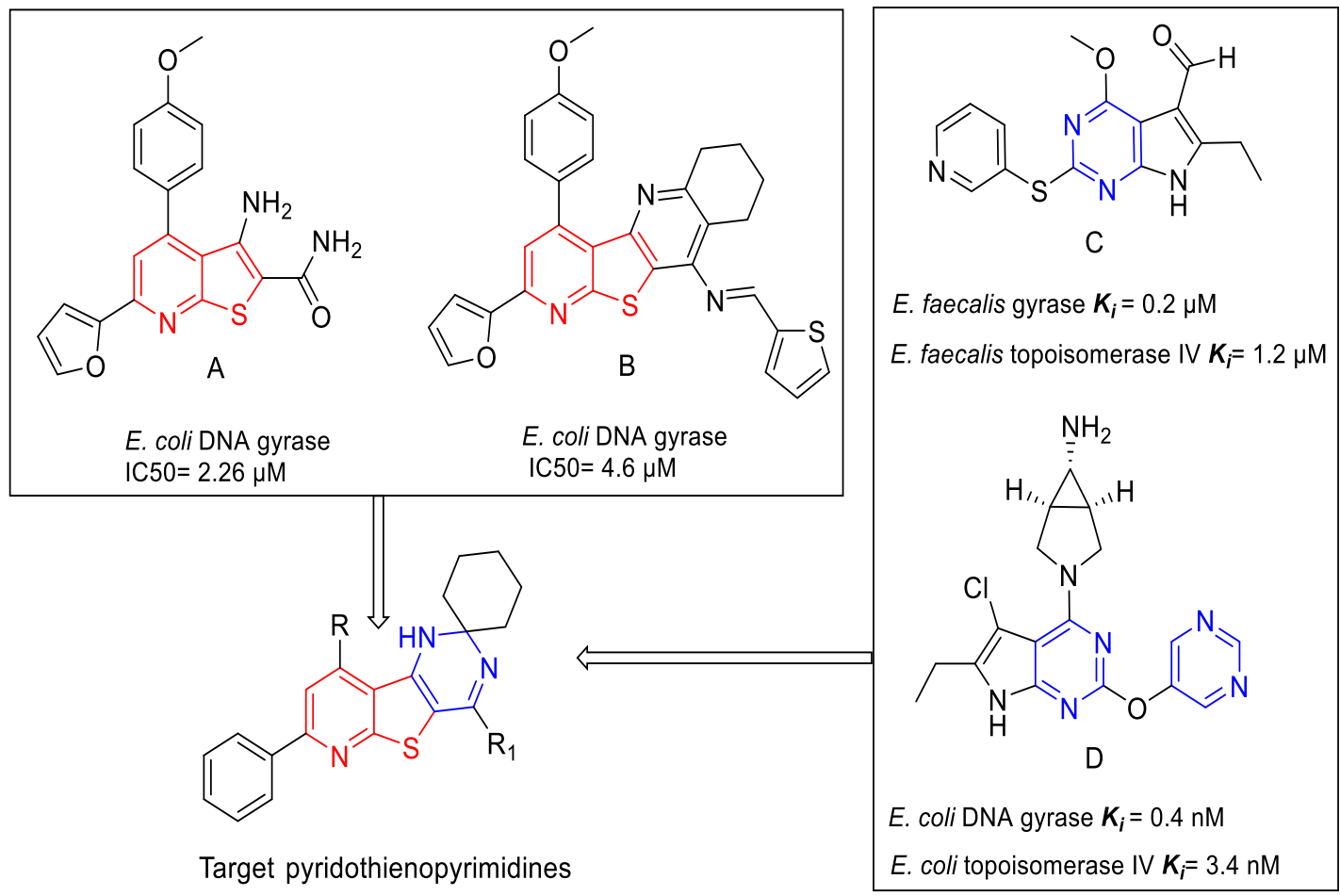

Figure 1. Recently discovered thienopyridines (A,B) and pyrimidine-based compounds (C,D) as bacterial type II topoisomerase inhibitors and the design of the target heterocyclic ring system.

\section{Results and Discussion}

\subsection{Chemistry}

The synthesis of the target pyridothienopyrimidines $(\mathbf{2} \mathbf{a}, \mathbf{b}-\mathbf{8} \mathbf{a}, \mathbf{b})$ was achieved via various reactions, as depicted in Scheme 1; Scheme 2. The starting 3-amino-6-phenylthieno[2,3-b]pyridine-2-carboxamides $\mathbf{1} \mathbf{a}, \mathbf{b}$ were prepared $[44,45]$ and underwent a cyclocondensation reaction with cyclohexanone in refluxing $\mathrm{N}, \mathrm{N}$-dimethyformamide containing anhydrous zinc chloride to produce $1^{\prime} \mathrm{H}$-spiro[cyclohexane$1,2^{\prime}$-pyrido $\left[3^{\prime}, 2^{\prime}: 4,5\right]$ thieno[3,2-d]pyrimidin]-4' $\left(3^{\prime} H\right)$-ones $\mathbf{2 a}, \mathbf{b}$. The chemical structures of $\mathbf{2 a}, \mathbf{b}$ were confirmed by their ${ }^{1} \mathrm{H}$ NMR spectra, which revealed signals at 1.21-2.02 ppm, corresponding to the $5 \mathrm{CH}_{2}$ protons of the spiro cyclohexane ring and two signals corresponding to the $2 \mathrm{NH}$ groups of the pyrimidinone ring at 4.53 and $7.90 \mathrm{ppm}$ and 4.90 and $7.88 \mathrm{ppm}$ for $\mathbf{2 a}$ and $\mathbf{2 b}$, respectively. Furthermore, the ${ }^{13} \mathrm{C}$ NMR spectra of $\mathbf{2 a} \mathbf{a} \mathbf{b}$ displayed three signals at 21.6-36.2 ppm of the $5 \mathrm{CH}_{2}$ carbons and a signal corresponding to the spiro carbon of $\mathbf{2 a}$ at $69.9 \mathrm{ppm}$ and a signal at $69.8 \mathrm{ppm}$ for that of $\mathbf{2} \mathbf{b}$. Subsequently, treatment of $\mathbf{2} \mathbf{a}, \mathbf{b}$ with a refluxing $\mathrm{POCl}_{3} / \mathrm{PCl}_{5}$ mixture gave $4^{\prime}$-chloro derivatives $\mathbf{3 a}, \mathbf{b}$. Then the target $1^{\prime} H$-spiro[cyclohexane-1,2'-pyrido[3', 2':4,5]thieno[3,2-d]pyrimidin]-4'-amines $4 \mathbf{a}$-e were obtained by carrying out a nucleophilic substitution reaction between $4^{\prime}$-chloro derivatives $\mathbf{3 a}, \mathbf{b}$ and different amines (furan-2-amine, 1-methylpiperazine, morpholine, 4-acetylaniline and 4-fluoroaniline) in boiling DMF (Scheme 1). In the ${ }^{1} \mathrm{H}$ NMR spectrum of $4 \mathbf{b}$, the protons of the $N$-methylpiperazinyl moiety were verified by three signals at 2.21, 2.59 and $3.75 \mathrm{ppm}$. The ${ }^{13} \mathrm{C} \mathrm{NMR} \mathrm{spectrum} \mathrm{of} 4 \mathrm{c}$ also showed the carbons of a morpholine ring as two signals at 45.5 and $66.4 \mathrm{ppm}$, corresponding to the $2 \mathrm{CH}_{2} \mathrm{~N}$ and $2 \mathrm{CH}_{2} \mathrm{O}$ moieties, respectively. 


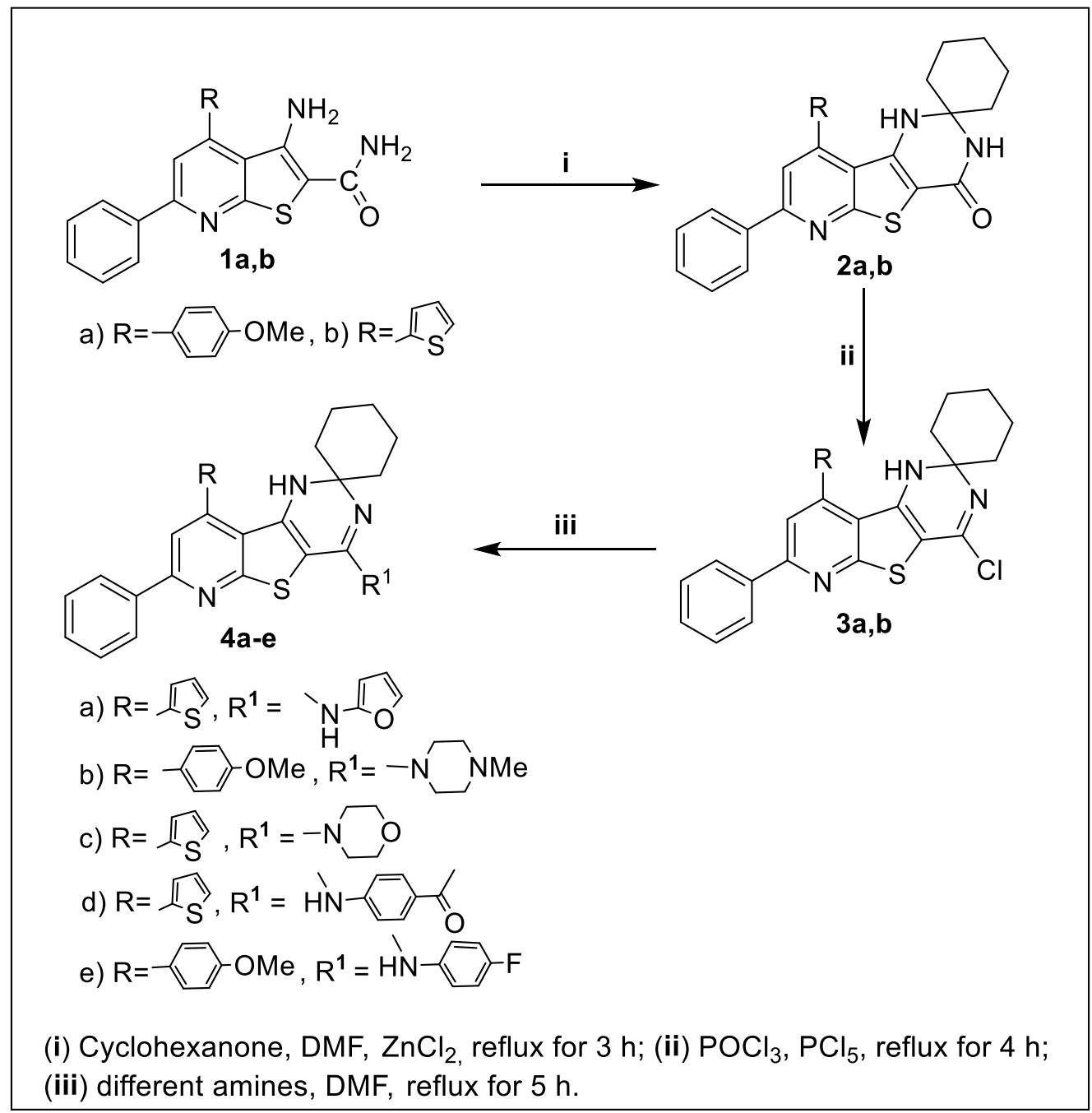

Scheme 1. Synthesis of the pyridothienopyrimidine derivatives $\mathbf{2 a}, \mathbf{b}-\mathbf{4} \mathbf{a} \mathbf{a}-\mathbf{e}$.

Upon treatment of $\mathbf{2} \mathbf{a}, \mathbf{b}$ with phosphorus pentasulfide in refluxing pyridine, the pyrido[ $\left[3^{\prime}, 2^{\prime}\right.$ : $4,5]$ thieno[3,2-d]pyrimidine]-4' $\left(3^{\prime} H\right)$-thiones $\mathbf{5} \mathbf{a}, \mathbf{b}$ were formed. IR spectra of $\mathbf{5 a}, \mathbf{b}$ displayed new bands at $1246.2 \mathrm{~cm}^{-1}$ and $1243.2 \mathrm{~cm}^{-1}$, corresponding to the $C=S$ groups of $\mathbf{5 a}$ and $\mathbf{5 b}$, besides the disappearance of the $\mathrm{C}=\mathrm{O}$ bands of $\mathbf{2 a}, \mathbf{b}$ at 1658.2 and $1659.4 \mathrm{~cm}^{-1}$, respectively. The signal at $181.3 \mathrm{ppm}$ in the ${ }^{13} \mathrm{C}$ NMR spectrum of $\mathbf{5 a}$ and at $182.1 \mathrm{ppm}$ in the ${ }^{13} \mathrm{C}$ NMR spectrum of $\mathbf{5} \mathbf{b}$ also assisted the presence of the $\mathrm{C}=\mathrm{S}$ carbon. Subsequent reaction of $4^{\prime}\left(3^{\prime} H\right)$-thiones $\mathbf{5 a} \mathbf{a} \mathbf{b}$ with ethyl 2-chloroacete in DMF containing a catalytic amount of anhydrous sodium carbonate afforded the formation of ethyl 2-(pyrido[3',2':4,5]thieno[3,2-d]pyrimidin-4'-yl)thio)acetates $\mathbf{6 a}, \mathbf{b}$ via S-alkylation at position 4. The steric hindrance of the bulky spiro cyclohexane moiety was a possible explanation for the forbidding of $\mathrm{N}$-alkylation at position $1 .{ }^{1} \mathrm{H}$ NMR spectra of $\mathbf{6 a}$ showed a singlet signal at $3.89 \mathrm{ppm}$ of $\mathrm{SCH}_{2}$ protons, while the $\mathrm{CH}_{3}$ and $\mathrm{CH}_{2} \mathrm{O}$ protons of the ester group were represented by the triplet signal at $1.07 \mathrm{ppm}$ and quartet signal at $4.08 \mathrm{ppm}$, respectively. The ${ }^{13} \mathrm{C}$ NMR spectrum of $6 \mathbf{b}$ also confirmed the occurrence of S-alkylation through the disappearance of the $C=S$ signal at $182.1 \mathrm{ppm}$, adding to the presence of four new signals at 32.8,168.7, 61.5 and $14.1 \mathrm{ppm}$, corresponding to the carbon of $\mathrm{SCH}_{2}$ and the three carbons $\left(\mathrm{C}=\mathrm{O}, \mathrm{OCH}_{2}\right.$ and $\left.\mathrm{CH}_{3}\right)$ of the ester group, respectively. Then, the condensation reaction of the esters $\mathbf{6 a}, \mathbf{b}$ with hydrazine hydrate in refluxing ethanol gave the acetohydrazide derivatives $\mathbf{7 a}, \mathbf{b}$. Furthermore, $N^{\prime}$-(arylidene)-acetohydrazide derivatives $\mathbf{8 a}, \mathbf{b}$ were obtained by carrying out a nucleophilic addition-elimination reaction between $7 \mathbf{a}$ and an aromatic 
aldehyde (4- $N, N$-dimethylaminobenzaldehyde and/or thiophene-2-carbaldehyde) in refluxing glacial acetic acid (Scheme 2).

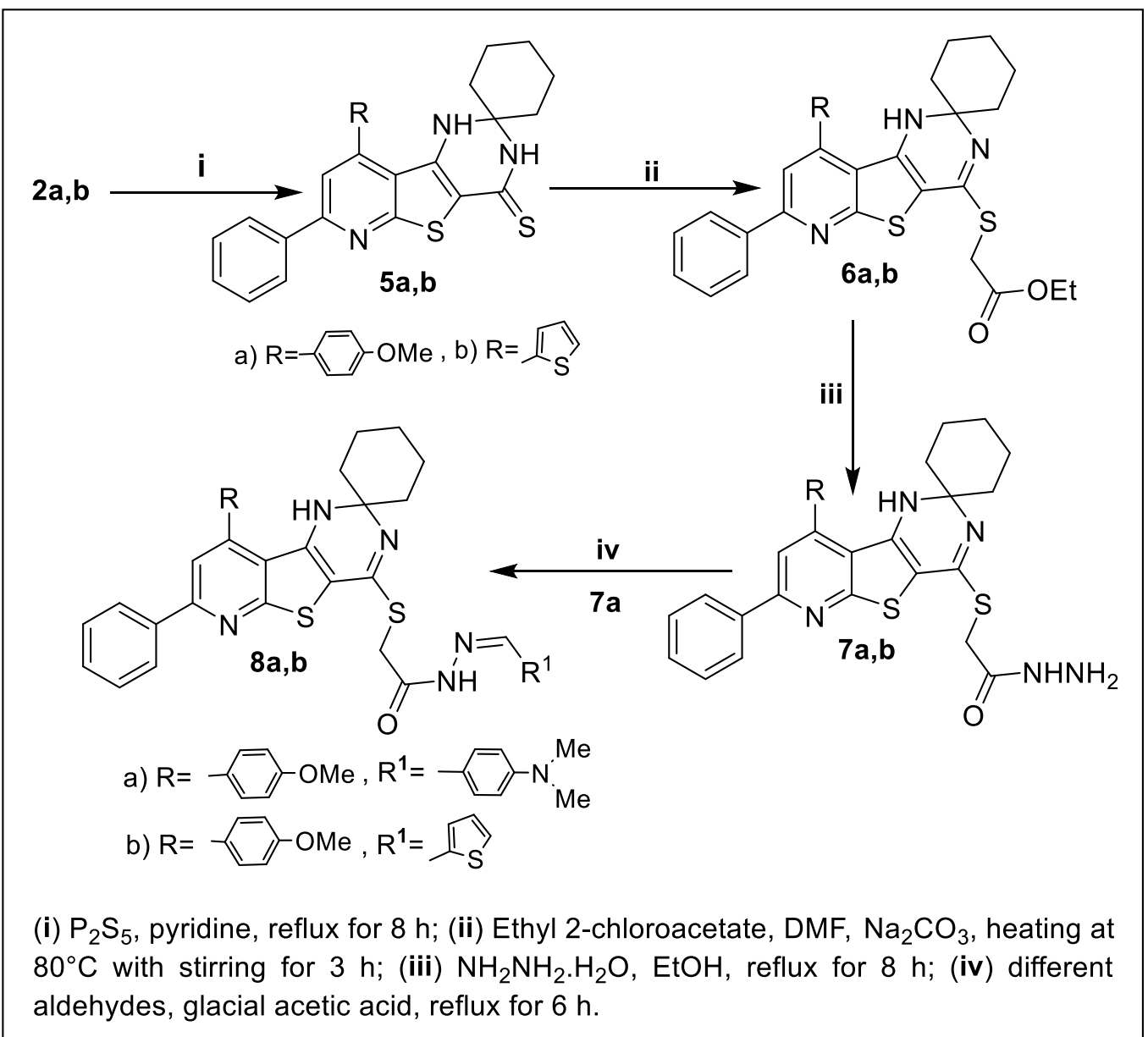

Scheme 2. Synthesis of the pyridothienopyrimidine derivatives $\mathbf{5 a}, \mathbf{b}-\mathbf{8} \mathbf{a}, \mathbf{b}$.

In the ${ }^{1} \mathrm{H}$ NMR spectrum of $7 \mathbf{a}$, beside the absence of ester signals, the hydrazide moiety was represented by two signals at $4.62 \mathrm{ppm}$ and $9.18 \mathrm{ppm}$, corresponding to the $\mathrm{NH}_{2}$ and $\mathrm{NH}$ groups, respectively. The ${ }^{1} \mathrm{H}$ NMR spectrum of $N^{\prime}$-(4-(dimethylamino)benzylidene derivative 8a also supported the presence of the arylidine moiety by a signal at $3.18 \mathrm{ppm}$ for the six protons dimethylamino group $\left(\mathrm{N}\left(\mathrm{CH}_{3}\right)_{2}\right)$ and a signal at $8.43 \mathrm{ppm}$ for the proton of the azomethine group $(\mathrm{CH}=\mathrm{N})$, as well the signals corresponding to new aromatic protons. Moreover, the ${ }^{13} \mathrm{C}$ NMR spectrum of $8 \mathbf{a}$ showed a signal at $44.7 \mathrm{ppm}$, corresponding to the two carbons of the $\mathrm{N}\left(\mathrm{CH}_{3}\right)_{2}$ group. The chemical structures of the new pyridothienopyrimidine derivatives (2a,b-8a,b) were confirmed by $\mathrm{IR},{ }^{1} \mathrm{H} N \mathrm{NMR},{ }^{13} \mathrm{C} \mathrm{NMR}$ and mass spectra, in addition to the correct results of their elemental microanalyses (Supplementary Materials: NMR spectra of compounds 2a,b-8a,b; Figures S1-S28).

\subsection{Antibacterial Activity}

The results of the in vitro antibacterial activity evaluation (MIC values in $\mu \mathrm{g} / \mathrm{mL}$ ) of the target pyridothienopyrimidine compounds (2a,b-8a,b), listed in Table 1 and Figure 2, revealed the significant activity of the majority of these compounds against the tested Gram-positive bacteria (Staphylococcus aureus 25923, Bacillus cereus 33018 and Bacillus subtilis 6633) and Gram-negative bacteria (Escherichia coli 8739, Salmonella typhimurium 14028 and Pseudomonas aeruginosa 27853) compared with amoxicillin trihydrate as a reference drug. In particular, the activity of the target compounds against the Gram-negative strains were more potent than their activity against the Gram-positive strains. In turn, 
pyrido[ $\left[3^{\prime}, 2^{\prime}: 4,5\right]$ thieno[3,2- $\left.d\right]$ pyrimidin]-4' $\left(3^{\prime} H\right)$-ones $\mathbf{2 a}$, $\mathbf{b}$ showed potent activity against all tested Gram-negative strains ( $\mathrm{MIC}=15.63 \mu \mathrm{g} / \mathrm{mL}$ ), equal to that of the reference drug, but they had no activity against all tested Gram-positive strains at the highest used concentration $(125 \mu \mathrm{g} / \mathrm{mL})$. The $4^{\prime}$-chloro derivatives $\mathbf{3 a}, \mathbf{b}$ also revealed inhibition activity against Gram-negative strains, the same as amoxicillin, with enhancement in the activity against the Gram-positive strains, especially against $S$. aureus $(\mathrm{MIC}=15.63 \mu \mathrm{g} / \mathrm{mL})$. Further increases in the potency of antibacterial activity against Gram-positive strains were observed in the $4^{\prime}$-amine derivatives $4 a-e$, especially against $B$. subtilis (MIC $=15.63 \mu \mathrm{g} / \mathrm{mL}$ ). The antibacterial activity of $4 \mathbf{a}-\mathbf{e}$ against the Gram-negative strains varied from potent to moderate, with MIC values ranging from 7.81 to $31.25 \mu \mathrm{g} / \mathrm{mL}$. Moreover, 4'-(4-methylpiperazin-1-yl) derivative $4 \mathbf{b}$ showed potent activity against all the tested bacterial strains, with MIC values ranging from 7.81 to $15.63 \mu \mathrm{g} / \mathrm{mL}$, which was equal in potency or more potent than that of amoxicillin. The conversion of $4^{\prime}\left(3^{\prime} H\right)$-ones $\mathbf{2} \mathbf{a}, \mathbf{b}$ to $4^{\prime}\left(3^{\prime} H\right)$-thiones $\mathbf{5 a}, \mathbf{b}$ also enhanced the antimicrobial activity against Gram-positive bacteria and showed inhibition activity ranging from potent to moderate against the three tested microorganisms, with MIC values ranging from 15.63 to $31.25 \mu \mathrm{g} / \mathrm{mL}$. On the reverse, the esters $\mathbf{6 a}, \mathbf{b}$ showed dramatic lowering in their activity; they were inactive against the Gram-positive strains and gave moderate or weak activity against the Gram-negative strains (MIC $=31.25 \mu \mathrm{g} / \mathrm{mL}$ and $62.5 \mu \mathrm{g} / \mathrm{mL}$ ).

Table 1. Minimum Inhibitory Concentration (MIC) values in $\mu \mathrm{g} / \mathrm{mL}$ of all the target compounds against different bacterial strains.

\begin{tabular}{ccccccc}
\hline \multirow{2}{*}{ Compound } & \multicolumn{3}{c}{ Gram-Positive Bacteria } & \multicolumn{3}{c}{ Gram-Negative Bacteria } \\
\cline { 2 - 6 } & S. aureus & B. subtilis & B. cereus & E. coli & S. typhimurium & P. aeruginosa \\
\hline $\mathbf{2 a}$ & $>125$ & $>125$ & $>125$ & 15.63 & 15.63 & 15.63 \\
$\mathbf{2 b}$ & $>125$ & $>125$ & $>125$ & 15.63 & 15.63 & 15.63 \\
$\mathbf{3 a}$ & 15.63 & 31.25 & 62.5 & 15.63 & 15.63 & 15.63 \\
$\mathbf{3 b}$ & 15.63 & 62.5 & 31.25 & 15.63 & 15.63 & 15.63 \\
$\mathbf{4 a}$ & 31.25 & 15.63 & 15.63 & 15.63 & 7.81 & 7.63 \\
$\mathbf{4 b}$ & 15.63 & 15.63 & 7.81 & 15.63 & 7.81 & 15.63 \\
$\mathbf{4 c}$ & 15.63 & 15.63 & 31.25 & 31.25 & 15.63 & 15.63 \\
$\mathbf{4 d}$ & 15.63 & 15.63 & 31.25 & 31.25 & 15.63 & 31.25 \\
$\mathbf{4 e}$ & 15.63 & 15.63 & 31.25 & 31.25 & 15.63 & 15.63 \\
$\mathbf{5 a}$ & 15.63 & 31.25 & 31.25 & 15.63 & 15.63 & 62.5 \\
$\mathbf{5 b}$ & 15.63 & 15.63 & 31.25 & 15.63 & 15.63 & 31.25 \\
$\mathbf{6 a}$ & $>125$ & $>125$ & $>125$ & 62.5 & 31.25 & 31.25 \\
$\mathbf{6 b}$ & $>125$ & $>125$ & 62.5 & 31.25 & 62.5 & 31.25 \\
$\mathbf{7 a}$ & 31.25 & 62.5 & 31.25 & 31.25 & 31.25 & 31.25 \\
$\mathbf{7 b}$ & 62.5 & 31.25 & 62.5 & 31.25 & 31.25 & 31.25 \\
$\mathbf{8 a}$ & 31.25 & 62.5 & 31.25 & 31.25 & 31.25 & 15.63 \\
$\mathbf{8 b}$ & 31.25 & 31.25 & 62.5 & 31.25 & 31.25 & 15.63 \\
\hline
\end{tabular}

However, the transformation of the esters $\mathbf{6} \mathbf{a}, \mathbf{b}$ to acetohydrazide derivatives $\mathbf{7 a}, \mathbf{b}$ and then to their arylidene derivatives $\mathbf{8} \mathbf{a}, \mathbf{b}$ revealed an improvement in the antibacterial activity against Gram-positive strains, with MIC values ranging from 31.25 to $62.5 \mu \mathrm{g} / \mathrm{mL}$. Moreover, $\mathbf{7 a}, \mathbf{b}$ and $\mathbf{8 a}, \mathbf{b}$ showed moderate activity against all tested Gram-negative strains (MIC $=31.25 \mu \mathrm{g} / \mathrm{mL}$ ). 


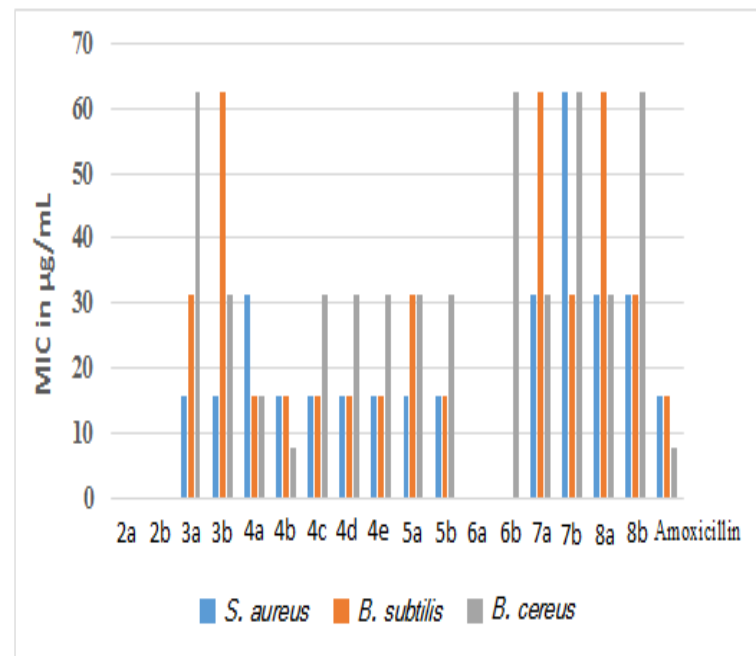

(a)

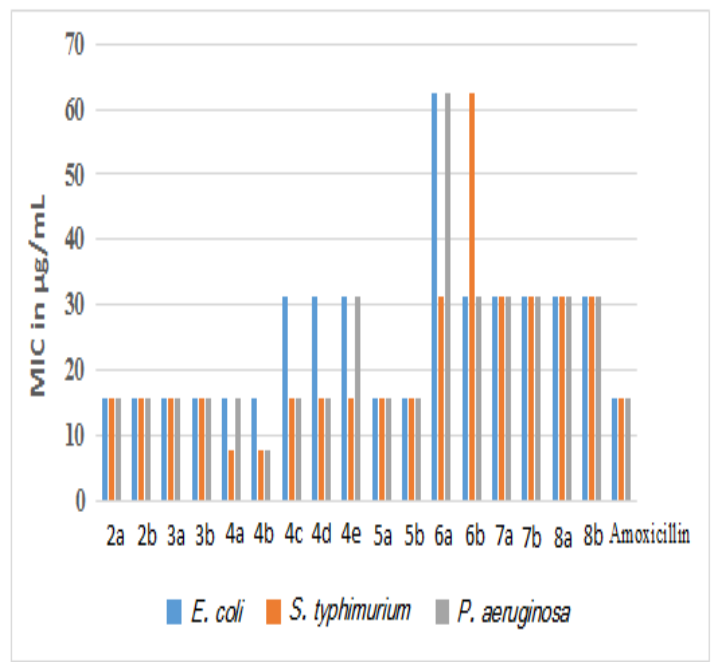

(b)

Figure 2. Antibacterial activity (MIC in $\mu \mathrm{g} / \mathrm{mL}$ ) of the target compounds against (a) three strains of Gram-positive bacteria and (b) three strains of Gram-negative bacteria.

\subsection{DNA Gyrase and Topoisomerase IV Inhibitory Activity}

The target compounds $(\mathbf{2} \mathbf{a}, \mathbf{b} ; \mathbf{3} \mathbf{a}, \mathbf{b} ; \mathbf{4} \mathbf{a}, \mathbf{b}$; and $\mathbf{5 a}, \mathbf{b})$ that showed the most potent activity against the tested Gram-negative bacteria, especially against $E$. coli, were chosen to evaluate their in vitro inhibitory activity of E. coli DNA gyrase and topoisomerase IV. The results of the DNA gyrase supercoiling and topoisomerase IV decatenation assays ( $\mathrm{IC}_{50}$ values in $\mu \mathrm{M}$ ) of these compounds are in Table 2, showing the potent dual inhibition of the $4^{\prime}$-amine derivatives $4 \mathbf{a} ; \mathbf{b}$ against both enzymes compared with the two reference inhibitors (ciprofloxacin and novobiocin). The 4'-(4-methyl-piperazin-1-yl)derivative $4 \mathrm{~b}$ was the most potent dual inhibitor with $\mathrm{IC}_{50}$ values of $3.44 \mu \mathrm{M}$ against DNA gyrase and $14.46 \mu \mathrm{M}$ against topoisomerase IV, while the $\mathrm{IC}_{50}$ values of ciprofloxacin and novobiocin were $3.52 \mu \mathrm{M}$ and $4.19 \mu \mathrm{M}$ for DNA gyrase and $17.57 \mu \mathrm{M}$ and $14.59 \mu \mathrm{M}$ for topoisomerase IV, respectively. $N$-(furan-2-yl)- 4'-amine derivative 4 a gave an $\mathrm{IC}_{50}$ value of $5.77 \mu \mathrm{M}$ against gyrase and showed a more potent inhibition of topoisomerase IV than that of ciprofloxacin, with an $\mathrm{IC}_{50}$ value of $14.89 \mu \mathrm{M}$. In addition, $4^{\prime}$-chloro derivative $\mathbf{3 b}$ and pyrimidin- $4^{\prime}\left(3^{\prime} H\right)$-thione derivative $\mathbf{5 b}$ revealed potent inhibitory activity against topoisomerase IV, with $\mathrm{IC}_{50}$ values of 17.50 and $17.24 \mu \mathrm{M}$, which were more potent than ciprofloxacin; however, they displayed moderate inhibition to DNA gyrase. The rest of the tested compounds, pyrimidin- $4^{\prime}\left(3^{\prime} H\right)$-ones $\mathbf{2} \mathbf{a}, \mathbf{b} ; 4^{\prime}$-chloro derivative $\mathbf{3 a}$ and pyrimidin- $4^{\prime}\left(3^{\prime} H\right)$-thione derivative $\mathbf{5 a}$, showed moderate inhibitory activity against both DNA gyrase and topoisomerase IV, with $\mathrm{IC}_{50}$ values ranging from 8.30 to $12.99 \mu \mathrm{M}$ and 21.78 to $23.25 \mu \mathrm{M}$, respectively.

\subsection{Molecular Docking Studies}

To explore the binding modes of the newly synthesized pyridothienopyrimidines $(\mathbf{2} \mathbf{a}, \mathbf{b} ; \mathbf{3} \mathbf{3}, \mathbf{b}$; $\mathbf{4 a}, \mathbf{b}$; and $\mathbf{5 a}, \mathbf{b})$ with the active site of E. coli DNA gyrase B, a molecular docking simulation was accomplished using MOE. Firstly, novobiocin (the original co-crystallized ligand) was re-docked in the active site of E. coli DNA gyrase B kinase ((PDB code: 1AJ6) [46,47] (Figure 3) and revealed a score energy of $-80 \mathrm{kcal} / \mathrm{mol}$ at a root mean square deviation (RMDS) value equal to $0.81 \AA$. As reported in docking of novobiocin, having a coumarin core linked to oxan-4-yl moiety, the protons of the hydroxyl group of oxan-4-yl and $\mathrm{NH}_{2}$ of the carbamate group formed hydrogen bonds within the active site of DNA gyrase B kinase via the backbone of Asp46 and the side chain of Asp73. Furthermore, the coumarin scaffold shared fixation through an arene-cation interaction with the essential amino acid Arg76 [37,47]. 
Table 2. Inhibitory activity of some selected compounds against $E$. coli DNA gyrase and topoisomerase IV enzymes.

2a
$\mathbf{3 b}$

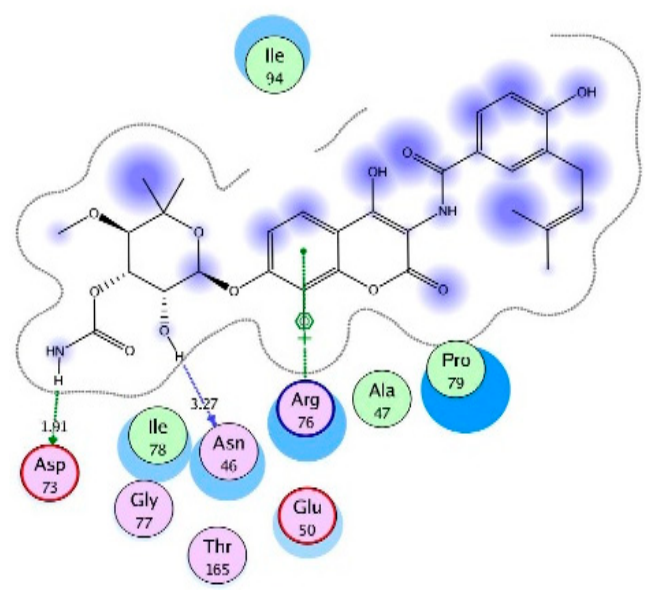

(a)

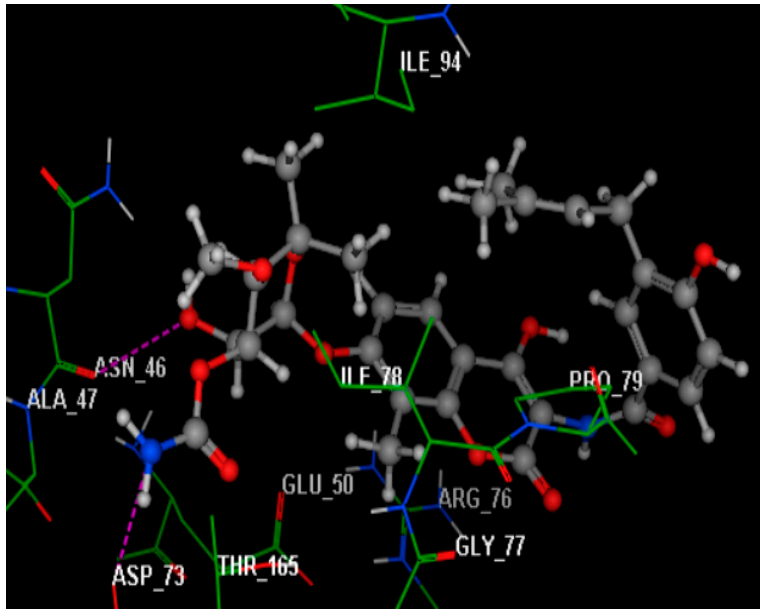

(b)

Figure 3. (a,b) Diagrams illustrating the 2D and 3D binding patterns of novobiocin onto the ATP-active pocket of E. coli DNA gyrase B kinase (PDB code: 1AJ6), respectively.

Then, the target compounds $(\mathbf{2} \mathbf{a}, \mathbf{b} ; \mathbf{3} \mathbf{a}, \mathbf{b} ; \mathbf{4} \mathbf{a}, \mathbf{b} ; \mathbf{5} \mathbf{a}, \mathbf{b})$ were docked into the ATP-active sites of E. coli DNA gyrase B and the docking results are listed in Table 3. By comparing the energy scores and the binding orientations of the target compounds with that of the original ligand novobiocin, it can be seen that all derivatives displayed promising energy scores ranging, from -5.25 to $-6.99 \mathrm{kcal} / \mathrm{mol}$ for E. coli DNA gyrase B, as well as a noticeable binding affinity between the pyridine scaffold and the essential amino acid Arg76 via an arene-cation interaction. The 4'-(4-methyl-piperazin-1-yl)- derivative 
$4 \mathbf{b}$, which displayed the most potent inhibitory activity, gave the highest binding affinity to DNA gyrase B, with an energy score of $-6.99 \mathrm{kcal} / \mathrm{mol}$. Moreover, the $N$-(furan-2-yl)-4'-amine derivative $4 \mathbf{a}$, which came after $\mathbf{4 b}$ in inhibition potency, displayed the second-best docking score, with a binding energy of $-6.64 \mathrm{kcal} / \mathrm{mol}$. Thus, compounds $4 \mathbf{a}$ and $4 \mathbf{b}$ were selected as the ligand examples against the structure of E. coli DNA gyrase B (PDB ID code: 1AJ6); the obtained docking models are illustrated in Figure 4; Figure 5.

Table 3. Docking results of compounds $\mathbf{2} \mathbf{a}, \mathbf{b} ; \mathbf{3} \mathbf{a}, \mathbf{b} ; \mathbf{4} \mathbf{a}, \mathbf{b}$; and $\mathbf{5 a}, \mathbf{b}$ with E. coli DNA gyrase B kinase using MOE software version 2008.10.

\begin{tabular}{|c|c|c|c|c|}
\hline $\begin{array}{l}\text { Compound } \\
\text { No. }\end{array}$ & $\begin{array}{l}\text { Docking Score } \\
\text { (Kcal/mol) }\end{array}$ & $\begin{array}{l}\text { Amino Acid Residues } \\
\text { (Bond Length } A^{0} \text { ) }\end{array}$ & Atoms of Compound & Type of Bond \\
\hline \multirow{3}{*}{ Novobiocin } & \multirow{3}{*}{-6.80} & Asn46(3.27); & $\mathrm{H}(\mathrm{OH})($ oxan-4-yl); & H-don \\
\hline & & Asp73(1.91); & $\mathrm{H}\left(\mathrm{OCONH}_{2}\right)$ & H-don \\
\hline & & Arg76 & $\mathrm{C}_{6} \mathrm{H}_{2}$ (coumarin) & Arene-cation \\
\hline \multirow{2}{*}{$2 a$} & \multirow{2}{*}{-5.25} & Arg76; & pyridine; & Arene-cation \\
\hline & & Gly77(2.79) & $\mathrm{O}$ (pyrimidone) & $\mathrm{H}-\mathrm{acc}$ \\
\hline \multirow{2}{*}{$2 b$} & \multirow{2}{*}{-5.74} & Arg76; & pyridine; & Arene-cation \\
\hline & & Gly77(2.25) & $\mathrm{O}$ (pyrimidone) & $\mathrm{H}-\mathrm{acc}$ \\
\hline \multirow{2}{*}{$3 a$} & \multirow{2}{*}{-5.65} & Arg76; & pyridine; & Arene-cation \\
\hline & & Thr165(2.50) & N-3(pyrimidine) & $\mathrm{H}$-acc \\
\hline \multirow{2}{*}{$3 b$} & \multirow{2}{*}{-5.90} & Arg76; & pyridine; & Arene-cation \\
\hline & & Thr165(2.27) & N-3(pyrimidine) & $\mathrm{H}-\mathrm{acc}$ \\
\hline \multirow{3}{*}{$4 a$} & \multirow{3}{*}{-6.64} & Arg76; & pyridine; & Arene-cation \\
\hline & & Thr165(2.15) & H(NH-furan-2-yl) & H-don \\
\hline & & Asn46(2.99); & N(piperazine); & $\mathrm{H}$-acc \\
\hline \multirow{2}{*}{$4 b$} & \multirow[t]{2}{*}{-6.99} & Arg76; & pyridine; & Arene-cation \\
\hline & & Arg76 & phenyl & Arene-cation \\
\hline $5 a$ & -5.30 & Arg76 & pyridine & Arene-cation \\
\hline $5 b$ & -5.55 & Arg76 & pyridine & Arene-cation \\
\hline
\end{tabular}

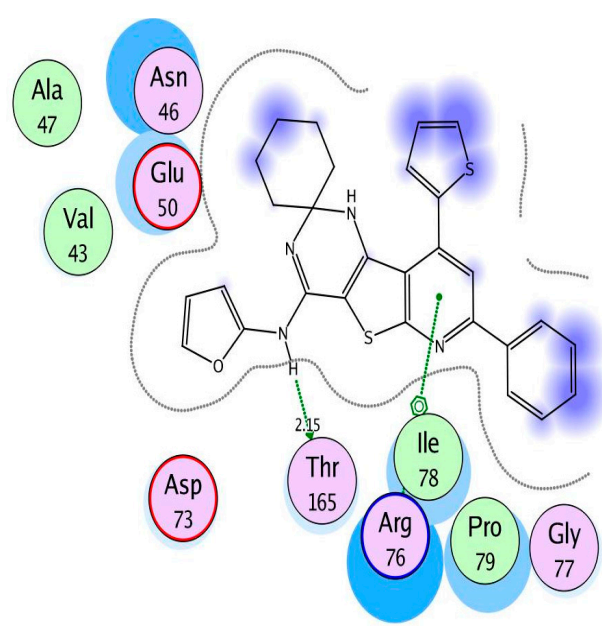

(a)

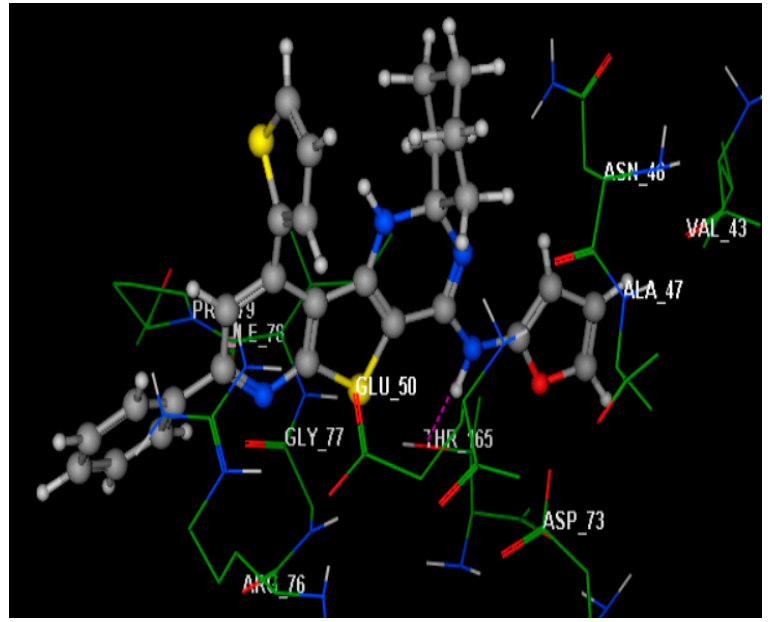

(b)

Figure 4. (a,b) Diagrams illustrating the $2 \mathrm{D}$ and $3 \mathrm{D}$ binding patterns of compound $4 \mathbf{a}$ onto the ATP-active pocket of E. coli DNA gyrase B kinase (PDB code: 1AJ6), respectively. 


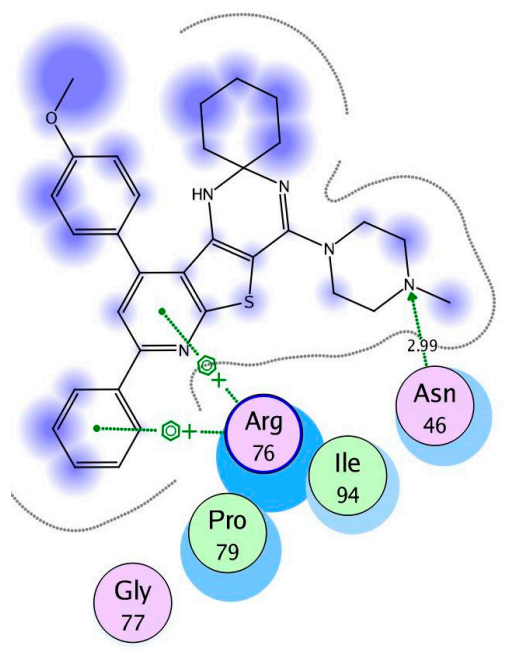

(a)

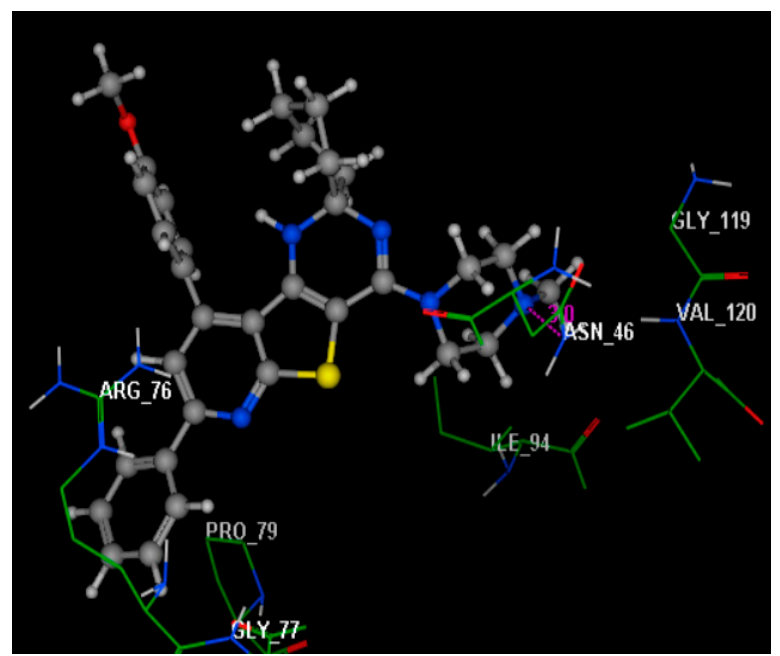

(b)

Figure 5. (a,b) Diagrams illustrating the $2 \mathrm{D}$ and $3 \mathrm{D}$ binding patterns of compound $\mathbf{4} \mathbf{b}$ onto the ATP-active pocket of E. coli DNA gyrase B kinase (PDB code: 1AJ6), respectively.

Regarding to the binding of 4a with E. coli DNA gyrase B, there was an H-bond donor between the NH proton of amino-2-furan scaffold with the side chain of Thr165 (distance: $2.15 \AA$ ), and it exhibited one arene-cation interaction with Arg76 (Figure 4). However, the pyridine and phenyl moieties of $4 \mathbf{b}$ demonstrated two arene-cation interactions with the key amino acid Arg76. Furthermore, the nitrogen of piperazine moiety of $\mathbf{4 b}$ formed with the side chain of Asn 46 a favorable hydrogen bonding (distance: $2.99 \AA$ A ) (Figure 5).

\section{Materials and Methods}

\subsection{Chemistry}

\subsubsection{General Consideration}

Melting points were determined by open glass capillary tubes using an Electro thermal IA9100 digital melting point apparatus and were uncorrected. Elemental microanalyses were carried out at the Micro Analytical Unit at Cairo University and were found within $\pm 0.5 \% .{ }^{1} \mathrm{H} N \mathrm{NR}$ and ${ }^{13} \mathrm{C}$ NMR spectra were recorded on a Bruker High Performance Digital FT-NMR Spectrometer Advance III (400/100 MHz) in the presence of TMS as the internal standard. Infrared spectra were recorded by using the $\mathrm{KBr}$ disc technique on a Jasco FT/IR-6100, Fourier transform, Infrared spectrometer (Japan) at the $\mathrm{cm}^{-1}$ scale. The ESI-mass spectra were measured using an Advion Compact Mass Spectrometer (CMS) NY, USA. Follow-up of the reactions and checking the purity of the compounds were made by TLC on silica gel aluminum sheets (Type 60, F 254, Merck, Darmstadt, Germany) and the spots were illustrated by exposure to UV analysis lamp at $\lambda 254 / 366 \mathrm{~nm}$ or by iodine vapor. The nomenclature of the new synthesized compounds is according to the IUPAC system. The starting 3-amino-6-phenylthieno[2,3-b]pyridine-2-carboxamides $\mathbf{1 a}$, b were prepared as per reported methods $[44,45]$.

\subsubsection{Synthesis of Pyrido[3',2':4,5]Thieno[3,2-d]Pyrimidin]-4'(3'H)-ones $2 \mathbf{a}, \mathbf{b}$}

A mixture of compounds $\mathbf{1 a}, \mathbf{b}(0.01 \mathrm{~mol})$ and cyclohexanone $(1.47 \mathrm{~g}, 0.015 \mathrm{~mol})$ in $\mathrm{N}, \mathrm{N}$-dimethyformamide $(20 \mathrm{~mL})$ containing anhydrous $\mathrm{ZnCl}_{2}(1.36 \mathrm{~g}, 0.01 \mathrm{~mol})$ was refluxed for 3 $\mathrm{h}$. The reaction mixture was poured onto ice/water and the obtained solid was collected by filtration, washed several times with water and recrystallized from $\mathrm{DMF} / \mathrm{H}_{2} \mathrm{O}$ to give compounds $\mathbf{2} \mathbf{a}, \mathbf{b}$. 
9'-(4-Methoxyphenyl)-7'-phenyl-1'H-spiro[cyclohexane-1,2'-pyrido[3',2':4,5]thieno[3,2-d]pyrimidin]-4' (3'H)-one (2a). It was a yellow powder, yield $81 \%$ (3.69 g), m.p. $295-296{ }^{\circ} \mathrm{C}$. Anal. calcd. (\%) for $\mathrm{C}_{27} \mathrm{H}_{25} \mathrm{~N}_{3} \mathrm{O}_{2} \mathrm{~S}$ (455.58): C, 71.18; H, 5.53; N, 9.22; S, 7.04. Found: $\mathrm{C}, 71.35 ; \mathrm{H}, 5.37 ; \mathrm{N}, 9.43 ; \mathrm{S}, 6.88$. ${ }^{1} \mathrm{H}$ NMR (DMSO-d6, $\left.400 \mathrm{MHz}\right): \delta 1.21-1.97\left(\mathrm{~m}, 10 \mathrm{H}, 5 \mathrm{CH}_{2}\right), 3.86\left(\mathrm{~s}, 3 \mathrm{H}, \mathrm{OCH}_{3}\right), 4.53(\mathrm{~s}, 1 \mathrm{H}, \mathrm{NH})$, $7.18(\mathrm{~d}, \mathrm{~J}=7.2 \mathrm{~Hz}, 2 \mathrm{H}, \mathrm{Ar}-\mathrm{H}), 7.48-7.55(\mathrm{~m}, 3 \mathrm{H}, \mathrm{Ar}-\mathrm{H}), 7.58(\mathrm{~d}, \mathrm{~J}=7.2 \mathrm{~Hz}, 2 \mathrm{H}, \mathrm{Ar}-\mathrm{H}), 7.86(\mathrm{~s}, 1 \mathrm{H}$, $\mathrm{Ar}-\mathrm{H}), 7.90(\mathrm{~s}, 1 \mathrm{H}, \mathrm{NH}), 8.22(\mathrm{~d}, \mathrm{~J}=6.0 \mathrm{~Hz}, 2 \mathrm{H}, \mathrm{Ar}-\mathrm{H}) .{ }^{13} \mathrm{C}$ NMR (DMSO-d $\left.6,100 \mathrm{MHz}\right): \delta 21.6,24.5$, $36.1\left(5 \mathrm{CH}_{2}\right), 56.0\left(\mathrm{OCH}_{3}\right), 69.9$ (spiro C), 114.5, 119.3, 122.8, 127.6, 129.3, 130.7, 133.6, 135.0, 139.6, 149.8, 154.8, 158.3, 161.5 (Ar-C), 167.9 (C=O). IR ( $\left.\mathrm{KBr}, v_{\max } \mathrm{cm}^{-1}\right)$ : 3419.2, $3281.5(\mathrm{NH}), 3047.3,2924.1,2856.4$ $(\mathrm{CH}), 1658.2(\mathrm{C}=\mathrm{O})$. ESI-MS: $m / z=454.61\left[\mathrm{M}-\mathrm{H}^{+}\right]$.

7'-Phenyl-9'-(thiophen-2-yl)-1'H-spiro[cyclohexane-1,2'-pyrido[3',2':4,5]thieno[3,2-d]pyrimidin]-4' $\left(3^{\prime} \mathrm{H}\right)$-one (2b). It was a yellow powder, yield 79\% (3.40 g), m.p. $289^{\circ} \mathrm{C}$. Anal. calcd. (\%) for $\mathrm{C}_{24} \mathrm{H}_{21} \mathrm{~N}_{3} \mathrm{OS}_{2}$ (431.57): C, 66.79; H, 4.90; N, 9.74; S, 14.86. Found: C, 66.65; H, 5.15; N, 9.49; S, 14.62. ${ }^{1} \mathrm{H}$ NMR (DMSO- $d_{6}$, $400 \mathrm{MHz}): \delta 1.21-2.02\left(\mathrm{~m}, 10 \mathrm{H}, 5 \mathrm{CH}_{2}\right), 4.90(\mathrm{~s}, 1 \mathrm{H}, \mathrm{NH}), 7.34(\mathrm{dd}, J=3.5,4.7 \mathrm{~Hz}, 1 \mathrm{H}, \mathrm{Ar}-\mathrm{H}), 7.51-7.55$ $(\mathrm{m}, 4 \mathrm{H}, \mathrm{Ar}-\mathrm{H}), 7.88(\mathrm{~s}, 1 \mathrm{H}, \mathrm{NH}), 7.93-7.98(\mathrm{~m}, 2 \mathrm{H}, \mathrm{Ar}-\mathrm{H}), 8.22-8.25(\mathrm{~m}, 2 \mathrm{H}, \mathrm{Ar}-\mathrm{H}) .{ }^{13} \mathrm{C}$ NMR (DMSO- $d_{6}$, $100 \mathrm{MHz}$ ): $\delta$ 21.8, 24.6, $36.2\left(5 \mathrm{CH}_{2}\right), 69.8$ (spiro C), 119.2, 122.3, 127.7, 128.2, 129.4, 130.1, 133.8, 139.9, 140.4, 145.2, 149.8, 156.0, 158.1 (Ar-C), $167.1(\mathrm{C}=\mathrm{O}) . \mathrm{IR}\left(\mathrm{KBr}, v_{\max } \mathrm{cm}^{-1}\right)$ : 3418.6, 3277.2 (NH), 3053.9, 2925.3, $2857.2(\mathrm{CH}), 1659.3(\mathrm{C}=\mathrm{O})$. ESI-MS: $m / z=430.48\left[\mathrm{M}-\mathrm{H}^{+}\right]$.

\subsubsection{Synthesis of $4^{\prime}-$ Chloropyrido[ $\left[3^{\prime}, 2^{\prime}: 4,5\right]$ Thieno[3,2-d] Pyrimidine Derivatives 3a, $\mathbf{b}$}

To a solution of compounds $\mathbf{2 a}, \mathbf{b}(5 \mathrm{mmol})$ in phosphorus oxychloride $(15 \mathrm{~mL})$, phosphorus pentachloride ( $1.04 \mathrm{~g}, 5 \mathrm{mmol}$ ) was added. The reaction mixture was refluxed for $4 \mathrm{~h}$, then left to cool and poured slowly with stirring onto crushed ice. The medium was neutralized with aqueous ammonia (28\%) to a $\mathrm{pH}$ of 7 ; the obtained solid was filtered off, washed with water and recrystallized from ethanol to give $4^{\prime}$-chloro derivatives $3 \mathbf{a}, \mathbf{b}$.

4'-Chloro-9'-(4-methoxyphenyl)-7'-phenyl-1'H-spiro[cyclohexane-1,2'-pyrido[3',2':4,5] thieno[3,2-d] pyrimidine] (3a). It was a pale-yellow powder, yield $68 \%(1.61 \mathrm{~g})$, m.p. $201-202^{\circ} \mathrm{C}$. Anal. calcd. (\%) for $\mathrm{C}_{27} \mathrm{H}_{24} \mathrm{ClN}_{3} \mathrm{OS}$ (474.02): C, 68.41; H, 5.10; N, 8.86; S, 6.76. Found: C, 68.28; H, 5.32; N, 8.59;, , 6.97. ${ }^{1} \mathrm{H}$ NMR (DMSO- $\left.d_{6}, 400 \mathrm{MHz}\right): \delta 1.28-1.87\left(\mathrm{~m}, 10 \mathrm{H}, 5 \mathrm{CH}_{2}\right), 3.85\left(\mathrm{~s}, 3 \mathrm{H}, \mathrm{OCH}_{3}\right), 7.03(\mathrm{~s}, 1 \mathrm{H}, \mathrm{NH})$, $7.15(\mathrm{~d}, J=8.4 \mathrm{~Hz}, 2 \mathrm{H}, \mathrm{Ar}-\mathrm{H}), 7.49-7.54(\mathrm{~m}, 3 \mathrm{H}, \mathrm{Ar}-\mathrm{H}), 7.74(\mathrm{~d}, J=8.4 \mathrm{~Hz}, 2 \mathrm{H}, \mathrm{Ar}-\mathrm{H}), 7.86(\mathrm{~s}, 1 \mathrm{H}$, Ar-H), $8.22(\mathrm{~d}, J=7.6 \mathrm{~Hz}, 2 \mathrm{H}, \mathrm{Ar}-\mathrm{H}) .{ }^{13} \mathrm{C}$ NMR $\left(\mathrm{DMSO}_{6}, 100 \mathrm{MHz}\right): \delta 22.1,24.6,36.2\left(5 \mathrm{CH}_{2}\right)$, $56.2\left(\mathrm{OCH}_{3}\right), 79.7$ (spiro C), 114.6, 119.4, 121.2, 123.4, 124.0, 127.6, 129.6, 130.5, 136.7, 139.6, 148.9, 149.7, 155.9, 161.4, 162.4 ( $\mathrm{Ar}-\mathrm{C}, \mathrm{C}=\mathrm{N})$. IR $\left(\mathrm{KBr}, v_{\max } \mathrm{cm}^{-1}\right)$ : $3384.2(\mathrm{NH}), 3058.5,2934.1,2848.3(\mathrm{CH}), 1608.6$ $(\mathrm{C}=\mathrm{N}), 764.4(\mathrm{C}-\mathrm{Cl})$. ESI-MS: $m / z=473.0\left[\mathrm{M}-\mathrm{H}^{+}\right]$.

4'-Chloro-7'-phenyl-9'-(thiophen-2-yl)-1'H-spiro[cyclohexane-1,2'-pyrido[3',2':4,5]thieno[3,2-d]pyrimidine] (3b). It was a buff powder, yield $66 \%(1.48 \mathrm{~g})$, m.p. $189^{\circ} \mathrm{C}$. Anal. calcd. (\%) for $\mathrm{C}_{24} \mathrm{H}_{20} \mathrm{ClN}_{3} \mathrm{~S}_{2}$ (450.02): C, 64.06; H, 4.48; N, 9.34; S, 14.25. Found: C, 64.25; H, 4.77; N, 9.11; S, 14.53. ${ }^{1} \mathrm{H}$ NMR (DMSO- $d_{6}$, $400 \mathrm{MHz}): \delta 1.24-1.87\left(\mathrm{~m}, 10 \mathrm{H}, 5 \mathrm{CH}_{2}\right), 6.92(\mathrm{~s}, 1 \mathrm{H}, \mathrm{NH}), 7.29(\mathrm{dd}, J=5.3,8.6 \mathrm{~Hz}, 1 \mathrm{H}, \mathrm{Ar}-\mathrm{H}), 7.50-7.58$ $(\mathrm{m}, 4 \mathrm{H}, \mathrm{Ar}-\mathrm{H}), 7.82-7.88(\mathrm{~m}, 2 \mathrm{H}, \mathrm{Ar}-\mathrm{H}), 8.21-8.27$ (m, 2H, Ar-H). ${ }^{13} \mathrm{C}$ NMR (DMSO- $d_{6}, 100 \mathrm{MHz}$ ): $\delta 21.5,24.1,36.0\left(5 \mathrm{CH}_{2}\right), 79.8$ (spiro C), 119.1, 121.7, 123.0, 125.5, 127.5, 129.3, 130.4, 139.7, 141.1, 145.2, 147.5, 156.0, 162.1 (Ar-C, C=N). IR (KBr, $\left.v_{\max } \mathrm{cm}^{-1}\right)$ : $3367.5(\mathrm{NH}), 3051.2,2925.1,2856.3(\mathrm{CH}), 1612.3$ $(\mathrm{C}=\mathrm{N}), 762.6(\mathrm{C}-\mathrm{Cl})$. ESI-MS: $m / z=449.04\left[\mathrm{M}-\mathrm{H}^{+}\right]$.

\subsubsection{Synthesis of Pyrido[ $\left[3^{\prime}, 2^{\prime}: 4,5\right]$ Thieno[3,2-d]Pyrimidin]-4'-Amines $4 \mathbf{a}-\mathbf{e}$}

A mixture of 4 -chloro derivatives $\mathbf{3 a}, \mathbf{b}(1 \mathrm{mmol})$ and different amines $(1 \mathrm{mmol})$ in $\mathrm{N}, \mathrm{N}$-dimethyformamide $(20 \mathrm{~mL})$ was heated under reflux for $5 \mathrm{~h}$. After reaction completion, the solvent was evaporated under vacuum and the oily residue was turned to solid by addition of dilute ethanol $(50 \%)$. The obtained solid was collected by filtration and recrystallized from acetone to give compounds $4 \mathbf{a}-\mathbf{e}$.

$N$-(furan-2-yl)-7'-phenyl-9'-(thiophen-2-yl)-1'H-spiro[cyclohexane-1,2'-pyrido[3', 2':4,5]thieno[3,2-d] pyrimidin]-4'-amine (4a) was synthesized from $3 \mathbf{b}(0.45 \mathrm{~g}, 1 \mathrm{mmol})$ and furan-2-amine $(0.084 \mathrm{~g}, 1 \mathrm{mmol})$ according to the general method. It was a brown powder, yield $72 \%(0.35 \mathrm{~g})$, m.p. $149^{\circ} \mathrm{C}$. Anal. calcd. 
(\%) for $\mathrm{C}_{28} \mathrm{H}_{24} \mathrm{~N}_{4} \mathrm{OS}_{2}$ (496.65): C, 67.72; $\mathrm{H}, 4.87 ; \mathrm{N}, 11.28 ; \mathrm{S}, 12.91$. Found: $\mathrm{C}, 67.94 ; \mathrm{H}, 4.61 ; \mathrm{N}, 11.54 ; \mathrm{S}$, 12.64. ${ }^{1} \mathrm{H}$ NMR (DMSO- $\left.d_{6}, 400 \mathrm{MHz}\right): \delta 1.20-2.01\left(\mathrm{~m}, 10 \mathrm{H}, 5 \mathrm{CH}_{2}\right), 6.75(\mathrm{~m}, 1 \mathrm{H}, \mathrm{Ar}-\mathrm{H}), 6.99(\mathrm{~s}, 1 \mathrm{H}$, $\mathrm{NH}), 7.23-7.35(\mathrm{~m}, 2 \mathrm{H}, \mathrm{Ar}-\mathrm{H}), 7.45-7.58(\mathrm{~m}, 4 \mathrm{H}, \mathrm{Ar}-\mathrm{H}), 7.81(\mathrm{~s}, 1 \mathrm{H}, \mathrm{Ar}-\mathrm{H}), 7.91(\mathrm{~d}, J=7.2 \mathrm{~Hz}, 1 \mathrm{H}$, $\mathrm{Ar}-\mathrm{H}), 8.00(\mathrm{~d}, J=10.4 \mathrm{~Hz}, 1 \mathrm{H}, \mathrm{Ar}-\mathrm{H}), 8.16-8.22(\mathrm{~m}, 2 \mathrm{H}, \mathrm{Ar}-\mathrm{H}), 8.78(\mathrm{~s}, 1 \mathrm{H}, \mathrm{NH}) .{ }^{13} \mathrm{C}$ NMR (DMSO- $d_{6}$, $100 \mathrm{MHz}$ ): $\delta 21.7,23.8,37.3\left(5 \mathrm{CH}_{2}\right), 79.8$ (spiro C), 107.8, 109.5, 119.4, 121.7, 123.2, 125.3, 127.4, 128.5, $129.5,130.2,139.7,141.6,143.8,144.2,145.2,148.1,155.2,156.3(\mathrm{Ar}-\mathrm{C}, \mathrm{C}=\mathrm{N})$. IR $\left(\mathrm{KBr}, v_{\max } \mathrm{cm}^{-1}\right)$ : 3432.6, 3366.2 (NH), 3061.1, 2925.2, 2857.4 (CH), 1640.2 (C=N). ESI-MS: $m / z=495.67\left[\mathrm{M}-\mathrm{H}^{+}\right]$.

9'-(4-Methoxyphenyl)-4'-(4-methylpiperazin-1-yl)-7'-phenyl-1'H-spiro[cyclohexane-1,2'-pyrido[3', $\left.2^{\prime}: 4,5\right]$ thieno[3,2-d]pyrimidine] $(4 \mathbf{b})$ was synthesized from $3 \mathbf{a}(0.47 \mathrm{~g}, 1 \mathrm{mmol})$ and 1-methylpiperazine $(0.10 \mathrm{~g}, 1 \mathrm{mmol})$ according to the general method. It was a beige powder, yield $74 \%(0.39 \mathrm{~g})$, m.p. $171^{\circ} \mathrm{C}$. Anal. calcd. (\%) for $\mathrm{C}_{32} \mathrm{H}_{35} \mathrm{~N}_{5} \mathrm{OS}$ (537.73): $\mathrm{C}, 71.48 ; \mathrm{H}, 6.56 ; \mathrm{N}, 13.02 ; \mathrm{S}, 5.96$. Found: $\mathrm{C}, 71.21 ; \mathrm{H}$, 6.27; N, 12.74; S, 5.68. ${ }^{1} \mathrm{H}$ NMR (DMSO-d $\left.6,400 \mathrm{MHz}\right): \delta 1.27-1.95\left(\mathrm{~m}, 10 \mathrm{H}, 5 \mathrm{CH}_{2}\right), 2.21\left(\mathrm{~s}, 3 \mathrm{H}, \mathrm{NCH}_{3}\right)$, $2.59\left(\mathrm{~s}, 4 \mathrm{H}, 2 \mathrm{CH}_{2} \mathrm{~N}\right), 3.75\left(\mathrm{~s}, 4 \mathrm{H}, 2 \mathrm{CH}_{2} \mathrm{~N}\right), 3.85\left(\mathrm{~s}, 3 \mathrm{H}, \mathrm{OCH}_{3}\right), 6.99(\mathrm{~s}, 1 \mathrm{H}, \mathrm{NH}), 7.13(\mathrm{~d}, \mathrm{~J}=9.2 \mathrm{~Hz}, 2 \mathrm{H}$, $\mathrm{Ar}-\mathrm{H}), 7.48-7.53(\mathrm{~m}, 3 \mathrm{H}, \mathrm{Ar}-\mathrm{H}), 7.73(\mathrm{~d}, \mathrm{~J}=9.2 \mathrm{~Hz}, 2 \mathrm{H}, \mathrm{Ar}-\mathrm{H}), 7.83(\mathrm{~s}, 1 \mathrm{H}, \mathrm{Ar}-\mathrm{H}), 8.23(\mathrm{~d}, \mathrm{~J}=5.2 \mathrm{~Hz}$, $2 \mathrm{H}, \mathrm{Ar}-\mathrm{H}) .{ }^{13} \mathrm{C}$ NMR (DMSO-d $\left.6,100 \mathrm{MHz}\right): \delta 21.8,24.4,36.4\left(5 \mathrm{CH}_{2}\right), 46.3\left(\mathrm{NCH}_{3}\right), 48.5\left(2 \mathrm{CH}_{2} \mathrm{~N}\right)$, $53.8\left(2 \mathrm{CH}_{2} \mathrm{~N}\right.$ ), $55.7\left(\mathrm{OCH}_{3}\right), 79.9$ (spiro C), 113.2, 119.8, 121.3, 122.9, 124.4, 127.6, 128.9 129.4, 130.1, 136.1, 141.1, 148.9, 149.6, 155.9, 157.2, $161.7(\mathrm{Ar}-\mathrm{C}, \mathrm{C}=\mathrm{N})$. IR (KBr, $\left.v_{\max } \mathrm{cm}^{-1}\right)$ : $3432.5(\mathrm{NH}), 3100.1$, 2925.4, $2857.2(\mathrm{CH}), 1640.1(\mathrm{C}=\mathrm{N})$. ESI-MS: $\mathrm{m} / \mathrm{z}=536.71\left[\mathrm{M}-\mathrm{H}^{+}\right]$.

4-(7'-Phenyl-9'-(thiophen-2-yl)-1'H-spiro[cyclohexane-1,2'-pyrido[3',2':4,5] thieno[3,2-d]pyrimidin]-4'-yl) morpholine (4c) was synthesized from $3 \mathbf{b}(0.45 \mathrm{~g}, 1 \mathrm{mmol})$ and morpholine $(0.087 \mathrm{~g}, 1 \mathrm{mmol})$ according to the general method. It was a brown powder, yield $76 \%(0.38 \mathrm{~g})$, m.p. $159-160{ }^{\circ} \mathrm{C}$. Anal. calcd. (\%) for $\mathrm{C}_{28} \mathrm{H}_{28} \mathrm{~N}_{4} \mathrm{OS}_{2}$ (500.68): $\mathrm{C}, 67.17 ; \mathrm{H}, 5.64 ; \mathrm{N}, 11.19 ; \mathrm{S}, 12.81$. Found: $\mathrm{C}, 66.89 ; \mathrm{H}, 5.31 ; \mathrm{N}, 11.47 ; \mathrm{S}$, 12.59. ${ }^{1} \mathrm{H}$ NMR (DMSO- $\left.\left.d_{6}, 400 \mathrm{MHz}\right): \delta 1.23-2.02\left(\mathrm{~m}, 10 \mathrm{H}, 5 \mathrm{CH}_{2}\right),\right), 3.06\left(\mathrm{~s}, 4 \mathrm{H}, 2 \mathrm{CH}_{2} \mathrm{~N}\right), 3.79(\mathrm{~s}, 4 \mathrm{H}$, $\left.2 \mathrm{CH}_{2} \mathrm{O}\right), 7.04(\mathrm{~s}, 1 \mathrm{H}, \mathrm{NH}), 7.33(\mathrm{~s}, 1 \mathrm{H}, \mathrm{Ar}-\mathrm{H}), 7.51-7.55(\mathrm{~m}, 4 \mathrm{H}, \mathrm{Ar}-\mathrm{H}), 7.84-7.90(\mathrm{~m}, 2 \mathrm{H}, \mathrm{Ar}-\mathrm{H})$, $8.23(\mathrm{~d}, J=10.0 \mathrm{~Hz}, 2 \mathrm{H}, \mathrm{Ar}-\mathrm{H}) .{ }^{13} \mathrm{C}$ NMR (DMSO- $\left.d_{6}, 100 \mathrm{MHz}\right): \delta 21.1,24.4,36.7\left(5 \mathrm{CH}_{2}\right), 45.5\left(2 \mathrm{CH}_{2} \mathrm{~N}\right)$, $66.4\left(2 \mathrm{CH}_{2} \mathrm{O}\right.$ ), 80.1 (spiro C), 119.2, 121.2, 123.4, 125.0, 127.1, 127.5, 128.6, 129.5, 130.2, 139.7, 141.1, 145.7, 149.0, 155.8, 156.8 ( $\mathrm{Ar}-\mathrm{C}, \mathrm{C}=\mathrm{N}) . \mathrm{IR}\left(\mathrm{KBr}, v_{\max } \mathrm{cm}^{-1}\right)$ : $3428.3(\mathrm{NH}), 3107.2,2922.5,2852.1(\mathrm{CH})$, 1644.6 (C=N). ESI-MS: $m / z=499.61\left[\mathrm{M}-\mathrm{H}^{+}\right]$.

1-(4-((7'-phenyl-9'-(thiophen-2-yl)-1'H-spiro[cyclohexane-1,2'-pyrido[3',2':4,5]thieno[3,2-d]pyrimidin] $-4^{\prime}$-yl)amino)phenyl)ethan-1-one (4d) was synthesized from $3 \mathbf{b}(0.45 \mathrm{~g}, 1 \mathrm{mmol})$ and 4-acetylaniline $(0.13 \mathrm{~g}, 0.001 \mathrm{~mol})$ according to the general method. It was a brown powder, yield $66 \%(0.36 \mathrm{~g})$, m.p. 141-142 ${ }^{\circ} \mathrm{C}$. Anal. calcd. (\%) for $\mathrm{C}_{32} \mathrm{H}_{28} \mathrm{~N}_{4} \mathrm{OS}_{2}$ (548.72): C, 70.04; $\mathrm{H}, 5.14 ; \mathrm{N}, 10.21 ; \mathrm{S}, 11.69$. Found: $\mathrm{C}$, 70.33; H, 5.40; N, 10.53; S, 11.43. ${ }^{1} \mathrm{H}$ NMR (DMSO-d $\left.{ }_{6}, 400 \mathrm{MHz}\right): \delta 1.21-2.02\left(\mathrm{~m}, 10 \mathrm{H}, 5 \mathrm{CH}_{2}\right), 2.66(\mathrm{~s}$, $\left.3 \mathrm{H}, \mathrm{CH}_{3} \mathrm{CO}\right), 6.96(\mathrm{~s}, 1 \mathrm{H}, \mathrm{NH}), 7.29-7.35(\mathrm{~m}, 1 \mathrm{H}, \mathrm{Ar}-\mathrm{H}), 7.43(\mathrm{~d}, \mathrm{~J}=11.2 \mathrm{~Hz}, 2 \mathrm{H}, \mathrm{Ar}-\mathrm{H}), 7.51-7.55(\mathrm{~m}$, $4 \mathrm{H}, \mathrm{Ar}-\mathrm{H}), 7.77(\mathrm{~d}, \mathrm{~J}=11.2 \mathrm{~Hz}, 2 \mathrm{H}, \mathrm{Ar}-\mathrm{H}), 7.92-7.96(\mathrm{~m}, 2 \mathrm{H}, \mathrm{Ar}-\mathrm{H}), 8.21(\mathrm{~d}, \mathrm{~J}=6.0 \mathrm{~Hz}, 2 \mathrm{H}, \mathrm{Ar}-\mathrm{H})$, $10.63(\mathrm{~s}, 1 \mathrm{H}, \mathrm{NH}) .{ }^{13} \mathrm{C}$ NMR (DMSO-d $6,100 \mathrm{MHz}$ ): $\delta 21.8,24.6,29.4,36.2\left(5 \mathrm{CH}_{2}, \mathrm{CH}_{3}\right), 79.9$ (spiro C), $115.8,119.5,121.5,123.1,125.1,127.4,127.7,128.2,129.4,130.2,132.3,139.5,140.9,142.4,145.3,148.9$, 150.1, 155.7, 162.8 (Ar-C, C=N), 167.2 (C=O). IR (KBr, $\left.v_{\max } \mathrm{cm}^{-1}\right): 3416.2,3280.5(\mathrm{NH}), 3074.3,2923.2$,

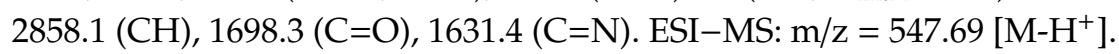

$N$-(4-fluorophenyl)-9'-(4-methoxyphenyl)-7'-phenyl-1'H-spiro[cyclohexane-1,2'-pyrido[3',2':4,5]thieno[3,2-d] pyrimidin]-4'-amine (4e) was synthesized from $3 \mathbf{a}(0.47 \mathrm{~g}, 1 \mathrm{mmol})$ and 4 -fluoroaniline $(0.11 \mathrm{~g}, 1 \mathrm{mmol})$ according to the general method. It was a brown powder, yield $67 \%(0.37 \mathrm{~g})$, m.p. $133-135{ }^{\circ} \mathrm{C}$. Anal. calcd. (\%) for $\mathrm{C}_{33} \mathrm{H}_{29} \mathrm{FN}_{4} \mathrm{OS}$ (548.68): $\mathrm{C}, 72.24 ; \mathrm{H}, 5.33 ; \mathrm{N}, 10.21 ; \mathrm{S}, 5.84$. Found: $\mathrm{C}, 72.61 ; \mathrm{H}, 5.64 ; \mathrm{N}$, 9.87; S, 5.46. 1H NMR (DMSO- $\left.d_{6}, 400 \mathrm{MHz}\right): \delta 1.22-1.84\left(\mathrm{~m}, 10 \mathrm{H}, 5 \mathrm{CH}_{2}\right), 3.85\left(\mathrm{~s}, 3 \mathrm{H}, \mathrm{OCH}_{3}\right), 6.78(\mathrm{~d}$, $J=9.6 \mathrm{~Hz}, 2 \mathrm{H}, \mathrm{Ar}-\mathrm{H}), 6.95(\mathrm{~s}, 1 \mathrm{H}, \mathrm{NH}), 7.13(\mathrm{~d}, J=7.2 \mathrm{~Hz}, 2 \mathrm{H}, \mathrm{Ar}-\mathrm{H}), 7.19(\mathrm{~d}, J=9.6 \mathrm{~Hz}, 2 \mathrm{H}, \mathrm{Ar}-\mathrm{H})$, 7.48-7.53 (m, 3H, Ar-H), $7.74(\mathrm{~d}, J=7.2 \mathrm{~Hz}, 2 \mathrm{H}, \mathrm{Ar}-\mathrm{H}), 7.84(\mathrm{~s}, 1 \mathrm{H}, \mathrm{Ar}-\mathrm{H}), 8.23(\mathrm{~d}, J=8.0 \mathrm{~Hz}, 2 \mathrm{H}$, $\mathrm{Ar}-\mathrm{H}), 10.26$ (s, 1H, NH). IR (KBr, $\left.v_{\max } \mathrm{cm}^{-1}\right)$ : 3410.2, 3335.4 (NH), 3065.1, 2924.5, $2856.2(\mathrm{CH}), 1628.4$ $(\mathrm{C}=\mathrm{N})$. ESI-MS: $m / z=547.64\left[\mathrm{M}-\mathrm{H}^{+}\right]$. 


\subsubsection{Synthesis of Pyrido[ $\left[3^{\prime}, 2^{\prime}: 4,5\right]$ Thieno[3,2- $\left.d\right]$ Pyrimidine $]-4^{\prime}\left(3^{\prime} H\right)$-Thiones $\mathbf{5 a}, \mathbf{b}$}

A mixture of compounds $2 \mathbf{a}, \mathbf{b}(0.01 \mathrm{~mol})$ and phosphorus pentasulfide $(2.22 \mathrm{~g}, 0.01 \mathrm{~mol})$ in pyridine $(30 \mathrm{~mL})$ was refluxed for $8 \mathrm{~h}$. After reaction completion, the reaction solution was poured onto cold water and left in the refrigerator overnight. The formed precipitate was separated by filtration, washed several times with water and recrystallized from $\mathrm{CHCl}_{3} /$ Pet. ether to give thione derivatives $\mathbf{5 a}, \mathbf{b}$.

9'-(4-Methoxyphenyl)-7'-phenyl-1'H-spiro[cyclohexane-1,2'-pyrido[3',2':4,5] thieno[3,2-d]pyrimidine]-4' (3'H)-thione (5a). It was an orange powder, yield 79\% (3.72 g), m.p. $254{ }^{\circ} \mathrm{C}$. Anal. calcd. (\%) for $\mathrm{C}_{27} \mathrm{H}_{25} \mathrm{~N}_{3} \mathrm{OS}_{2}$ (471.64): $\mathrm{C}, 68.76 ; \mathrm{H}, 5.34 ; \mathrm{N}, 8.91 ; \mathrm{S}, 13.60$. Found: $\mathrm{C}, 68.44 ; \mathrm{H}, 5.61 ; \mathrm{N}, 9.19 ; \mathrm{S}, 13.93$. ${ }^{1} \mathrm{H}$ NMR (DMSO-d6, $\left.400 \mathrm{MHz}\right): \delta 1.19-2.03\left(\mathrm{~m}, 10 \mathrm{H}, 5 \mathrm{CH}_{2}\right), 3.87\left(\mathrm{~s}, 3 \mathrm{H}, \mathrm{OCH}_{3}\right), 4.80(\mathrm{~s}, 1 \mathrm{H}, \mathrm{NH})$, $7.17(\mathrm{~d}, J=8.5 \mathrm{~Hz}, 2 \mathrm{H}, \mathrm{Ar}-\mathrm{H}), 7.51-7.55(\mathrm{~m}, 3 \mathrm{H}, \mathrm{Ar}-\mathrm{H}), 7.59(\mathrm{~d}, J=8.5 \mathrm{~Hz}, 2 \mathrm{H}, \mathrm{Ar}-\mathrm{H}), 7.84(\mathrm{~s}, 1 \mathrm{H}$, $\mathrm{Ar}-\mathrm{H}), 8.22(\mathrm{~d}, J=6.5 \mathrm{~Hz}, 2 \mathrm{H}, \mathrm{Ar}-\mathrm{H}), 9.69(\mathrm{~s}, 1 \mathrm{H}, \mathrm{NH}) .{ }^{13} \mathrm{C}$ NMR (DMSO-d $\left.6,100 \mathrm{MHz}\right): \delta 21.7,24.5$, $35.7\left(5 \mathrm{CH}_{2}\right), 56.0\left(\mathrm{OCH}_{3}\right), 70.2$ (spiro C), 114.5, 119.4, 121.7, 122.8, 127.6, 128.4, 129.5, 130.2, 134.2, 140.0, 147.8, 149.9, 154.8, 161.5, 163.1 (Ar-C), 181.3 (C=S). IR (KBr, $\left.v_{\max } \mathrm{cm}^{-1}\right)$ : 3417.5, $3251.4(\mathrm{NH}), 3042.1$, 2923.2, $2856.3(\mathrm{CH}), 1246.2(\mathrm{C}=\mathrm{S})$. ESI-MS: $\mathrm{m} / \mathrm{z}=470.58\left[\mathrm{M}-\mathrm{H}^{+}\right]$.

7'-Phenyl-9'-(thiophen-2-yl)-1'H-spiro[cyclohexane-1,2'-pyrido[3',2':4,5]thieno[3,2-d]pyrimidine]-4' $\left(3^{\prime} H\right)$ thione $(\mathbf{5 b})$. It was an orange powder, yield $81 \%(3.40 \mathrm{~g})$, m.p. $233-234{ }^{\circ} \mathrm{C}$. Anal. calcd. (\%) for $\mathrm{C}_{24} \mathrm{H}_{21} \mathrm{~N}_{3} \mathrm{~S}_{3}$ (447.63): C, 64.40; H, 4.73; N, 9.39; S, 21.49. Found: $\mathrm{C}, 64.78 ; \mathrm{H}, 5.01 ; \mathrm{N}, 9.17 ; \mathrm{S}, 21.71$. ${ }^{1} \mathrm{H}$ NMR (DMSO-d6, $\left.400 \mathrm{MHz}\right): \delta 1.18-2.06\left(\mathrm{~m}, 10 \mathrm{H}, 5 \mathrm{CH}_{2}\right), 5.15(\mathrm{~s}, 1 \mathrm{H}, \mathrm{NH}), 7.33(\mathrm{dd}, J=3.5,4.9 \mathrm{~Hz}$, $1 \mathrm{H}, \mathrm{Ar}-\mathrm{H}), 7.48-7.57(\mathrm{~m}, 4 \mathrm{H}, \mathrm{Ar}-\mathrm{H}), 7.92(\mathrm{~s}, 1 \mathrm{H}, \mathrm{Ar}-\mathrm{H}), 7.93(\mathrm{~s}, 1 \mathrm{H}, \mathrm{Ar}-\mathrm{H}), 8.21-8.25(\mathrm{~m}, 2 \mathrm{H}, \mathrm{Ar}-\mathrm{H})$, $9.78(\mathrm{~s}, 1 \mathrm{H}, \mathrm{NH}) .{ }^{13} \mathrm{C}$ NMR (DMSO-d $6,100 \mathrm{MHz}$ ): $\delta 21.6,24.6,35.3\left(5 \mathrm{CH}_{2}\right), 70.5$ (spiro C), 119.4, 121.4, 122.9, 127.7, 128.3, 129.4, 129.7, 130.5, 139.4, 141.3, 145.0, 148.3, 156.0, 162.6 (Ar-C), 182.1 (C=S). IR (KBr, $\left.v_{\max } \mathrm{cm}^{-1}\right): 3406.3,3240.4(\mathrm{NH}), 3105.1,2928.3,2854.1(\mathrm{CH}), 1243.2(\mathrm{C}=\mathrm{S})$. ESI-MS: $\mathrm{m} / \mathrm{z}=446.70$ $\left[\mathrm{M}-\mathrm{H}^{+}\right]$.

\subsubsection{Synthesis of Ethyl 2-(Pyrido[3',2':4,5]Thieno[3,2-d]Pyrimidin-4-yl-Thio)Acetates $\mathbf{6 a}, \mathbf{b}$}

A mixture of compounds $\mathbf{5 a}, \mathbf{b}(5 \mathrm{mmol})$ and ethyl 2-chloroacete $(0.60 \mathrm{~g}, 5 \mathrm{mmol})$ in $\mathrm{N}, \mathrm{N}$ dimethylformamide $(30 \mathrm{~mL})$ containing anhydrous sodium carbonate $(1.0 \mathrm{~g})$ was heated at $80^{\circ} \mathrm{C}$ with stirring for $3 \mathrm{~h}$. The reaction mixture was poured onto an ice-water mixture and left standing for $1 \mathrm{~h}$. The obtained solid was collected by filtration, washed with water, and recrystallized from ethanol to produce the esters $\mathbf{6 a}, \mathbf{b}$.

Ethyl2-((9'-(4-methoxyphenyl)-7'-phenyl-1'H-spiro[cyclohexane-1,2'-pyrido[3', 2':4,5] thieno[3,2-d] pyrimidin]-4'-yl)thio)acetate (6a). It was an off-white powder, yield $72 \%\left(2.0\right.$ g), m.p. $275-276{ }^{\circ} \mathrm{C}$. Anal. calcd. (\%) for $\mathrm{C}_{31} \mathrm{H}_{31} \mathrm{~N}_{3} \mathrm{O}_{3} \mathrm{~S}_{2}$ (557.73): $\mathrm{C}, 66.76 ; \mathrm{H}, 5.60 ; \mathrm{N}, 7.53 ; \mathrm{S}, 11.50$. Found: $\mathrm{C}, 66.43 ; \mathrm{H}, 5.88 ; \mathrm{N}$, 7.81; S, 11.17. 1H NMR (DMSO-d6, $400 \mathrm{MHz}): \delta 1.07\left(\mathrm{t}, J=10.8 \mathrm{~Hz}, 3 \mathrm{H}, \mathrm{CH}_{3} \mathrm{CH}_{2}\right), 1.28-1.96(\mathrm{~m}, 10 \mathrm{H}$, $\left.5 \mathrm{CH}_{2}\right), 3.86\left(\mathrm{~s}, 3 \mathrm{H}, \mathrm{OCH}_{3}\right), 3.89\left(\mathrm{~s}, 2 \mathrm{H}, \mathrm{SCH}_{2}\right), 4.08\left(\mathrm{q}, J=10.8 \mathrm{~Hz}, 2 \mathrm{H}, \mathrm{OCH}_{2} \mathrm{CH}_{3}\right), 7.05(\mathrm{~s}, 1 \mathrm{H}, \mathrm{NH})$, $7.14(\mathrm{~d}, J=7.6 \mathrm{~Hz}, 2 \mathrm{H}, \mathrm{Ar}-\mathrm{H}), 7.50-7.54(\mathrm{~m}, 3 \mathrm{H}, \mathrm{Ar}-\mathrm{H}), 7.72(\mathrm{~d}, J=7.6 \mathrm{~Hz}, 2 \mathrm{H}, \mathrm{Ar}-\mathrm{H}), 7.89(\mathrm{~s}, 1 \mathrm{H}$, $\mathrm{Ar}-\mathrm{H}), 8.23(\mathrm{~d}, J=10.0 \mathrm{~Hz}, 2 \mathrm{H}, \mathrm{Ar}-\mathrm{H})$. IR $\left(\mathrm{KBr}, v_{\max } \mathrm{cm}^{-1}\right)$ : 3410.3(NH), 3058.1, 2924.2, $2860.4(\mathrm{CH})$, $1735.2(\mathrm{C}=\mathrm{O})$. ESI-MS: $\mathrm{m} / \mathrm{z}=556.68[\mathrm{M}-\mathrm{H}+]$.

Ethyl2-((7'-phenyl-9'-(thiophen-2-yl)-1'H-spiro[cyclohexane-1,2'-pyrido[3',2':4,5] thieno[3,2-d] pyrimidin]-4'-yl)thio)acetate (6b). It was a pale-yellow powder, yield $69 \%(1.84 \mathrm{~g})$, m.p. $261-262{ }^{\circ} \mathrm{C}$. Anal. calcd. (\%) for $\mathrm{C}_{28} \mathrm{H}_{27} \mathrm{~N}_{3} \mathrm{O}_{2} \mathrm{~S}_{3}$ (533.72): $\mathrm{C}, 63.01 ; \mathrm{H}, 5.10 ; \mathrm{N}, 7.87 ; \mathrm{S}, 18.02$. Found: $\mathrm{C}, 63.29 ; \mathrm{H}, 5.35 ; \mathrm{N}$, 7.54; S, 18.33. ${ }^{1} \mathrm{H}$ NMR (DMSO-d6, $\left.400 \mathrm{MHz}\right): \delta 1.11\left(\mathrm{t}, J=13.2 \mathrm{~Hz}, 3 \mathrm{H}, \mathrm{CH}_{3} \mathrm{CH}_{2}\right), 1.28-1.88(\mathrm{~m}, 10 \mathrm{H}$, $\left.5 \mathrm{CH}_{2}\right), 3.90\left(\mathrm{~s}, 2 \mathrm{H}, \mathrm{SCH}_{2}\right), 3.96\left(\mathrm{q}, J=13.2 \mathrm{~Hz}, 2 \mathrm{H}, \mathrm{OCH}_{2} \mathrm{CH}_{3}\right), 6.94(\mathrm{~s}, 1 \mathrm{H}, \mathrm{NH}), 7.39-7.70(\mathrm{~m}, 5 \mathrm{H}$, Ar-H), 7.87-7.95 (m, 2H, Ar-H), $8.23(\mathrm{~m}, 2 \mathrm{H}, \mathrm{Ar}-\mathrm{H}) .{ }^{13} \mathrm{C}$ NMR (DMSO-d $\left.6,100 \mathrm{MHz}\right): \delta 14.1\left(\mathrm{CH}_{3}\right)$, 21.7, 25.5, 32.8, 35.8 $\left(5 \mathrm{CH}_{2}, \mathrm{SCH}_{2}\right), 61.5\left(\mathrm{CH}_{2} \mathrm{O}\right), 80.6$ (spiro C), 119.2, 122.0, 124.1, 125.6, 127.8, 128.6, 129.5, 130.2, 139.8, 141.1, 144.8, 145.7, 156.4, $163.1(\mathrm{Ar}-\mathrm{C}, \mathrm{C}=\mathrm{N}), 168.7(\mathrm{C}=\mathrm{O}) . \mathrm{IR}\left(\mathrm{KBr}, v_{\max } \mathrm{cm}^{-1}\right)$ : 3417.2 (NH), 3068.0, 2926.4, 2863.2 (CH), $1736.5(\mathrm{C}=\mathrm{O})$. ESI-MS: $\mathrm{m} / \mathrm{z}=532.76\left[\mathrm{M}-\mathrm{H}^{+}\right]$. 


\subsubsection{Synthesis of Pyrido $\left[3^{\prime}, 2^{\prime}: 4,5\right]$ Thieno[3,2-d]Pyrimidin]-4'-yl)thio)Acetohydrazides $7 \mathbf{a}, \mathbf{b}$}

A mixture of $\mathbf{6 a}, \mathbf{b}(0.004 \mathrm{~mol})$ and hydrazine hydrate $98 \%(1 \mathrm{~mL}$, excess) in absolute ethanol $(50 \mathrm{~mL})$ was refluxed for $8 \mathrm{~h}$. After reaction completion, the obtained solid was collected by filtration and recrystallized from $\mathrm{DMF} / \mathrm{H}_{2} \mathrm{O}$ to give acetohydrazide derivatives $\mathbf{7 a}, \mathbf{b}$.

2-((9'-(4-methoxyphenyl)-7'-phenyl-1'H-spiro[cyclohexane-1,2'-pyrido[3', 2':4,5]thieno[3,2-d] pyrimidin]-4'-yl)thio)acetohydrazide (7a). It was a red powder, yield $66 \%(1.43 \mathrm{~g}), \mathrm{m} . \mathrm{p} .234^{\circ} \mathrm{C}$. Anal. calcd. (\%) for $\mathrm{C}_{29} \mathrm{H}_{29} \mathrm{~N}_{5} \mathrm{O}_{2} \mathrm{~S}_{2}$ (543.70): $\mathrm{C}, 64.06 ; \mathrm{H}, 5.38 ; \mathrm{N}, 12.88 ; \mathrm{S}, 11.79$. Found: $\mathrm{C}, 64.33 ; \mathrm{H}, 5.65$; $\mathrm{N}, 13.16$; S, 11.47. ${ }^{1} \mathrm{H}$ NMR (DMSO-d6, $\left.400 \mathrm{MHz}\right): \delta 1.26-1.99\left(\mathrm{~m}, 10 \mathrm{H}, 5 \mathrm{CH}_{2}\right), 3.86\left(\mathrm{~s}, 3 \mathrm{H}, \mathrm{OCH}_{3}\right)$, $3.89\left(\mathrm{~s}, 2 \mathrm{H}, \mathrm{SCH}_{2}\right), 4.62\left(\mathrm{~s}, 2 \mathrm{H}, \mathrm{NH}_{2}\right), 7.05(\mathrm{~s}, 1 \mathrm{H}, \mathrm{NH}), 7.17(\mathrm{~d}, \mathrm{~J}=8.6 \mathrm{~Hz}, 2 \mathrm{H}, \mathrm{Ar}-\mathrm{H}), 7.49-7.59(\mathrm{~m}$, $3 \mathrm{H}, \mathrm{Ar}-\mathrm{H}), 7.74(\mathrm{~d}, \mathrm{~J}=8.6 \mathrm{~Hz}, 2 \mathrm{H}, \mathrm{Ar}-\mathrm{H}), 7.84(\mathrm{~s}, 1 \mathrm{H}, \mathrm{Ar}-\mathrm{H}), 8.27(\mathrm{~d}, \mathrm{~J}=7.0 \mathrm{~Hz}, 2 \mathrm{H}, \mathrm{Ar}-\mathrm{H}), 9.18$ (s, $1 \mathrm{H}, \mathrm{NH})$. IR (KBr, $\left.v_{\max } \mathrm{cm}^{-1}\right)$ : 3410.3, 3320.3, 3240.1(NH), 3057.5, 2927.2, $2858.4(\mathrm{CH}), 1685.3(\mathrm{C}=\mathrm{O})$. ESI-MS: $\mathrm{m} / \mathrm{z}=542.73\left[\mathrm{M}-\mathrm{H}^{+}\right]$.

2-((7'-phenyl-9'-(thiophen-2-yl)-1'H-spiro[cyclohexane-1,2'-pyrido[3',2':4,5]thieno[3,2-d]pyrimidin]-4'-yl)thio) acetohydrazide $(7 \mathrm{~b})$. It was a red powder, yield $62 \%(1.29 \mathrm{~g})$, m.p. $222{ }^{\circ} \mathrm{C}$. Anal. calcd. (\%) for $\mathrm{C}_{26} \mathrm{H}_{25} \mathrm{~N}_{5} \mathrm{OS}_{3}$ (519.70): $\mathrm{C}, 60.09 ; \mathrm{H}, 4.85 ; \mathrm{N}, 13.48 ; \mathrm{S}, 18.51$. Found: $\mathrm{C}, 60.48 ; \mathrm{H}, 5.19 ; \mathrm{N}, 13.11 ; \mathrm{S}, 18.19$. ${ }^{1} \mathrm{H}$ NMR (DMSO-d6, $\left.400 \mathrm{MHz}\right): \delta 1.27-1.96\left(\mathrm{~m}, 10 \mathrm{H}, 5 \mathrm{CH}_{2}\right), 3.87\left(\mathrm{~s}, 2 \mathrm{H}, \mathrm{SCH}_{2}\right), 4.59\left(\mathrm{~s}, 2 \mathrm{H}, \mathrm{NH}_{2}\right)$, 6.99 (s, 1H, NH), 7.32-7.74 (m, 5H, Ar-H), 7.86-7.91 (m, 2H, Ar-H), $8.26(\mathrm{~m}, 2 \mathrm{H}, \mathrm{Ar}-\mathrm{H}), 9.22(\mathrm{~s}, 1 \mathrm{H}$, $\mathrm{NH})$. IR (KBr, $\left.v_{\max } \mathrm{cm}^{-1}\right)$ : 3414.3, 3326.1, $3251.4(\mathrm{NH}), 3061.1,2924.3,2857.2(\mathrm{CH}), 1680.1(\mathrm{C}=\mathrm{O})$. ESI-MS: $\mathrm{m} / \mathrm{z}=518.66\left[\mathrm{M}-\mathrm{H}^{+}\right]$.

3.1.8. Synthesis of $N^{\prime}$-(Arylidene)-2-(Pyrido[3',2':4,5]Thieno[3,2-d] Pyrimidin]-4'-yl)Thio) Acetohydrazides $\mathbf{8 a}, \mathbf{b}$

A mixture of $7 \mathbf{a}(0.54 \mathrm{~g}, 1 \mathrm{mmol})$ and different aldehydes, namely, 4-(dimethylamino)benzaldehyde and thiophene-2-carbaldehyde $(1 \mathrm{mmol})$ in glacial acetic acid $(20 \mathrm{~mL})$, was refluxed for $6 \mathrm{~h}$. After reaction completion, the reaction mixture was concentrated and poured onto cold water. The formed solid was collected by filtration, washed with water and recrystallized from ethanol to give compounds $\mathbf{8 a}, \mathbf{b}$.

N'-(4-(dimethylamino)benzylidene)-2-((9'-(4-methoxyphenyl)-7'-phenyl-1'H-spiro[cyclohexane1,2'-pyrido[3', 2':4,5]thieno[3,2-d]pyrimidin]-4'-yl)thio)acetohydrazide (8a). It was a brown powder, yield 61\% (0.41 g), m.p. $199-200{ }^{\circ} \mathrm{C}$. Anal. calcd. (\%) for $\mathrm{C}_{38} \mathrm{H}_{38} \mathrm{~N}_{6} \mathrm{O}_{2} \mathrm{~S}_{2}$ (674.88): C, 67.63; H, 5.68; N, 12.45; S, 9.50. Found: C, 67.31; H, 5.93; N, 12.69; S, 9.22. ${ }^{1} \mathrm{H}$ NMR (DMSO-d6, $\left.400 \mathrm{MHz}\right): \delta 1.23-1.92(\mathrm{~m}, 10 \mathrm{H}$, $\left.5 \mathrm{CH}_{2}\right), 3.01\left(\mathrm{~s}, 6 \mathrm{H}, \mathrm{N}\left(\mathrm{CH}_{3}\right)_{2}\right), 3.85\left(\mathrm{~s}, 3 \mathrm{H}, \mathrm{OCH}_{3}\right), 3.98\left(\mathrm{~s}, 2 \mathrm{H}, \mathrm{SCH}_{2}\right), 6.97(\mathrm{~s}, 1 \mathrm{H}, \mathrm{NH}), 7.16(\mathrm{~d}, \mathrm{~J}=8.4 \mathrm{~Hz}$, $2 \mathrm{H}, \mathrm{Ar}-\mathrm{H}), 7.22(\mathrm{~d}, \mathrm{~J}=9.6 \mathrm{~Hz}, 2 \mathrm{H}, \mathrm{Ar}-\mathrm{H}), 7.54-7.55(\mathrm{~m}, 3 \mathrm{H}, \mathrm{Ar}-\mathrm{H}), 7.74(\mathrm{~d}, \mathrm{~J}=8.4 \mathrm{~Hz}, 2 \mathrm{H}, \mathrm{Ar}-\mathrm{H})$, $7.87(\mathrm{~s}, 1 \mathrm{H}, \mathrm{Ar}-\mathrm{H}), 7.94(\mathrm{~d}, \mathrm{~J}=9.6 \mathrm{~Hz}, 2 \mathrm{H}, \mathrm{Ar}-\mathrm{H}), 8.26(\mathrm{~d}, \mathrm{~J}=7.2 \mathrm{~Hz}, 2 \mathrm{H}, \mathrm{Ar}-\mathrm{H}), 8.43(\mathrm{~s}, 1 \mathrm{H}, \mathrm{CH}=\mathrm{N})$, $11.14(\mathrm{~s}, 1 \mathrm{H}, \mathrm{NH}) .{ }^{13} \mathrm{C}$ NMR (DMSO-d $\left.6,100 \mathrm{MHz}\right): \delta 21.6,24.4,33.6,36.5\left(5 \mathrm{CH}_{2}, \mathrm{SCH}_{2}\right), 44.7\left(\mathrm{~N}\left(\mathrm{CH}_{3}\right)_{2}\right)$, $56.0\left(\mathrm{OCH}_{3}\right), 80.3$ (spiro C), 112.1, 114.6, 119.5, 121.6, 122.9, 124.5, 127.8, 128.2, 129.1, 129.9, 130.8, 134.7, 139.9, 145.1, 148.0, 150.1, 154.0, 155.2, 161.5, $163.6(\mathrm{Ar}-\mathrm{C}, \mathrm{CH}=\mathrm{N}), 169.9(\mathrm{C}=\mathrm{O})$. IR $\left(\mathrm{KBr}, v_{\max } \mathrm{cm}^{-1}\right)$ : 3417.1, 3325.5'(NH), 3066.2, 2924.2, 2853.3 (CH), $1678.1(\mathrm{C}=\mathrm{O})$. ESI-MS: $\mathrm{m} / \mathrm{z}=673.91\left[\mathrm{M}-\mathrm{H}^{+}\right]$.

2-((9'-(4-methoxyphenyl)-7'-phenyl-1'H-spiro[cyclohexane-1,2'-pyrido[3',2':4,5] thieno[3,2-d] pyrimidin]-4'-yl)thio)- $\mathrm{N}^{\prime}$-(thiophen-2-ylmethylene)acetohydrazide (8b). It was a buff powder, yield $63 \%$ (0.40 g), m.p. $178-179{ }^{\circ} \mathrm{C}$. Anal. calcd. (\%) for $\mathrm{C}_{34} \mathrm{H}_{31} \mathrm{~N}_{5} \mathrm{O}_{2} \mathrm{~S}_{3}$ (637.84): $\mathrm{C}, 64.03 ; \mathrm{H}, 4.90 ; \mathrm{N}, 10.98 ; \mathrm{S}, 15.08$. Found: C, 64.35; H, 5.17; N, 10.66; S, 15.36. ${ }^{1} \mathrm{H}$ NMR (DMSO-d6, $\left.400 \mathrm{MHz}\right): \delta 1.28-1.96\left(\mathrm{~m}, 10 \mathrm{H}, 5 \mathrm{CH}_{2}\right)$, $3.87\left(\mathrm{~s}, 3 \mathrm{H}, \mathrm{OCH}_{3}\right), 3.98\left(\mathrm{~s}, 2 \mathrm{H}, \mathrm{SCH}_{2}\right), 6.98(\mathrm{~s}, \mathrm{H}, \mathrm{NH}), 7.15(\mathrm{~d}, \mathrm{~J}=10.8 \mathrm{~Hz}, 2 \mathrm{H}, \mathrm{Ar}-\mathrm{H}), 7.39-7.98(\mathrm{~m}, 9 \mathrm{H}$, $\mathrm{Ar}-\mathrm{H}), 8.26(\mathrm{~d}, \mathrm{~J}=9.6 \mathrm{~Hz}, 2 \mathrm{H}, \mathrm{Ar}-\mathrm{H}), 8.53(\mathrm{~s}, 1 \mathrm{H}, \mathrm{CH}=\mathrm{N}), 10.96(\mathrm{~s}, 1 \mathrm{H}, \mathrm{NH}) . \mathrm{IR}\left(\mathrm{KBr}, v_{\max } \mathrm{cm}^{-1}\right): 3412.3$, $3310.2(\mathrm{NH}), 3069.1,2925.2,2857.4(\mathrm{CH}), 1680.5(\mathrm{C}=\mathrm{O})$. ESI-MS: $\mathrm{m} / \mathrm{z}=636.78\left[\mathrm{M}-\mathrm{H}^{+}\right]$.

\subsection{In Vitro Antibacterial Screening}

All the newly synthesized compounds (2a, $\mathbf{b}-\mathbf{8 a}, \mathbf{b})$ and the standard drug (amoxicillin trihydrate) were evaluated for their antibacterial activity against three strains of Gram-positive bacteria (S. aureus 25923, B. cereus 33018 and B. subtilis 6633) and three strains of Gram-negative bacteria (E. coli 8739, S. typhimurium 14028 and P. aeruginosa 27853) by using the broth dilution method [48]. A twofold serial 
dilution was performed to obtain the required concentrations $(125,62.5,31.25,15.63,7.81,3.91,1.95$ and $0.97, \mu \mathrm{g} / \mathrm{mL}$ ) for the target compounds and the reference drug. The minimum concentration of the sample that showed no growth of the tested microorganism (MIC) were specified; then the MIC values for the compounds and standard drug were listed (see Table 1).

\subsection{DNA Gyrase Supercoiling and Topoisomerase IV Decatenation Inhibition Assays}

Eight of the target compounds $(2 a, 2 b, 3 a, 3 b, 4 a, 4 b, 5 a$, and $5 b)$ were chosen to evaluate their inhibitory activity against bacterial type II topoisomerase enzymes. The assay kits of E. coli DNA gyrase supercoiling and E. coli topoisomerase IV decatenation were provided by TopoGEN, Inc. (Port Orange, FL) and the assays were performed according to established protocols obtained from the supplier [49]. The new compounds and two standard inhibitors (ciprofloxacin and novobiocin) were dissolved in DMSO and serially diluted at concentrations of $100,10,1$ and $0.1 \mu \mathrm{M}$, and then assayed in reaction mixtures in three different replicate runs. For DNA gyrase supercoiling: the final reaction volume was $20 \mu \mathrm{L}$, which included $35 \mathrm{mM}$ Tris $\mathrm{pH}$ 7, $2 \mathrm{mM}$ DTT, $24 \mathrm{mM} \mathrm{KCl}, 4 \mathrm{mM} \mathrm{MgCl}, 1.8 \mathrm{mM}$ spermidine, $0.1 \mathrm{mg} / \mathrm{mL}$ acetylated BSA, 6.5\% (w/v) glycerol, $1 \mathrm{mM}$ ATP, $0.1 \mathrm{mg} / \mathrm{mL}$ album and $0.2 \mathrm{mg}$ pBR322 substrate. While, for topoisomerase IV decatenation: the final reaction volume was $20 \mu \mathrm{L}$, containing $40 \mathrm{mM}$ Tris $\mathrm{pH}$ 7.5, $10 \mathrm{mM}$ DTT, $6 \mathrm{mM} \mathrm{MgCl} 2,100 \mathrm{mM}$ potassium glutamate, $1 \mathrm{mM} \mathrm{ATP}, 50 \mathrm{mg} / \mathrm{mL}$ acetylated BSA and $0.2 \mathrm{mg} \mathrm{kDNA}$ substrate. The reactions were initiated by addition of $2 \mathrm{U}$ of $E$.coli DNA gyrase or E.coli topoisomerase IV (TopoGen), and $3 \mu \mathrm{L}$ of inhibitor solution in 10\% DMSO, and then were incubated with shaking for $30 \mathrm{~min}$ at $37^{\circ} \mathrm{C}$. All of the reactions were terminated by the addition of $10 \mathrm{~mL}$ of a $3 \mathrm{X}$ gel-loading buffer (final concentration: $6 \mathrm{mM}$ EDTA, 1.2\% SDS, 0.02\% bromophenol blue, and 10\% glycerol blue), after which $20 \mathrm{~mL}$ of this was loaded on a $1 \%$ agarose, TAE (0.01 M EDTA pH 8.3, $40 \mathrm{mM}$ Tris-acetate) gel that was then run at $60 \mathrm{~V}$ for $3 \mathrm{~h}$. The gel was stained by $(0.5 \mathrm{mg} / \mathrm{L})$ ethidium bromide in TAE for $30 \mathrm{~min}$ and then de-stained in water for $20 \mathrm{~min}$. Fluorescent images were taken at a wavelength of $300 \mathrm{~nm}$ on a UV transilluminator imaging system. The fluorescence intensity of the supercoiled plasmid reaction product and the decatenation product, in the case of gyrase and topo IV, were quantitated using ImagQuant software (Molecular Dynamics, Sunnyvale, CA, USA). The results as IC50 values (concentration of the tested compound that leads to $50 \%$ inhibition of enzyme activity) for all samples were determined by nonlinear regression analysis in GraphPad Prism $[49,50]$. The average $\mathrm{IC}_{50}$ values $(\mu \mathrm{M})$ of the triplicate experiments were calculated for the target compounds and the two reference antibiotics and then listed in Table 2.

\subsection{Molecular Docking Study}

The molecular docking simulation study was done using Molecular Operating Environment $\left(\mathrm{MOE}^{\circledR}\right) 2008.10$ software [51]. The crystal structures of E. coli DNA gyrase B complexed with their ligand novobiocin (PDB codes: 1AJ6 and 1S14) [46,47] were retrieved from the Protein Data Bank. At the beginning, the co-crystallized ligand was re-docked into the assigned active E. coli DNA gyrase $\mathrm{B}$ enzyme to evaluate the root mean square deviation value. Then, the molecular docking procedure was performed for the newly synthesized compounds $(\mathbf{2} \mathbf{a}, \mathbf{b} ; \mathbf{3} \mathbf{3} \mathbf{a}, \mathbf{b} ; \mathbf{4} \mathbf{a}, \mathbf{b} ; \mathbf{5} \mathbf{a}, \mathbf{b})$ into the ATP-binding site of E. coli DNA gyrase B (PDB code: 1AJ6 and 1S14), following the reported method [37].

\section{Conclusions}

This work included synthesis of novel 4-substituted-1'H-spiro[cyclohexane-1,2'-pyrido[3', $\left.2^{\prime}: 4,5\right]$ thieno[3,2-d]pyrimidin] compounds $(\mathbf{2} \mathbf{a}, \mathbf{b}-\mathbf{8} \mathbf{a}, \mathbf{b})$ and the in vitro evaluation of these compounds against six strains of both Gram-positive and Gram-negative bacteria compared with amoxicillin trihydrate as a reference drug. The tested pyridothienopyrimidine compounds $(\mathbf{2} \mathbf{a}, \mathbf{b}-\mathbf{8} \mathbf{a}, \mathbf{b})$ showed significant antibacterial activity, especially against Gram-negative strains, with MIC values ranging from 7.81 to $62.5 \mu \mathrm{g} / \mathrm{mL}$. Compounds $\mathbf{2 a}, \mathbf{b} ; \mathbf{3} \mathbf{a}, \mathbf{b}$; and $\mathbf{5 a}, \mathbf{b}$ gave potent activity against all tested Gram-negative bacteria, equal to that of the reference drug, with an MIC value of $15.63 \mu \mathrm{g} / \mathrm{mL}$. The $N$-(furan-2-yl)-4'-amine derivative $4 \mathbf{a}$ also displayed potent activity against all Gram-negative strains, besides its potent to moderate 
activity against Gram-positive strains. Moreover, 4'-(4-methyl-piperazin-1-yl)- derivative $4 \mathrm{~b}$ was the most active compound compared with the reference drug; it gave potent activity against all the tested bacterial strains, with MIC values ranging from 7.81 to $15.63 \mu \mathrm{g} / \mathrm{mL}$. In turn, the antibacterial activity of compounds $\mathbf{6 a}, \mathbf{b} ; \mathbf{7 a}, \mathbf{b}$ and $\mathbf{8 a}, \mathbf{b}$ varied from weak, with an MIC value of $62.5 \mu \mathrm{g} / \mathrm{mL}$, to moderate, with an MIC value of $31.25 \mu \mathrm{g} / \mathrm{mL}$, against the tested microorganisms. Thus, compounds $\mathbf{2} \mathbf{a}, \mathbf{b} ; \mathbf{3} \mathbf{a}, \mathbf{b} ; \mathbf{4} \mathbf{a} \mathbf{a}, \mathbf{b}$ and $\mathbf{5} \mathbf{a}, \mathbf{b}$, because they were the most potent compounds against $E$. coli, were selected to evaluate their in vitro inhibitory activity of E. coli topoisomerase II enzymes (DNA gyrase and topoisomerase IV). The tested compounds showed dual inhibition of the two enzymes and their inhibitory activity varied from potent to moderate compared with the two reference antibiotics (ciprofloxacin and novobiocin). Furthermore, compound $4 \mathrm{~b}$ displayed dual inhibition, and was more potent than the two references, with $\mathrm{IC}_{50}$ values of $3.44 \mu \mathrm{M}$ and $14.46 \mu \mathrm{M}$ against DNA gyrase and topoisomerase IV, respectively. Furthermore, $4 \mathbf{a}$ came after $4 \mathbf{b}$ in inhibition potency with $\mathrm{IC}_{50}$ values of $5.77 \mu \mathrm{M}$ for DNA gyrase and $14.89 \mu \mathrm{M}$ for topoisomerase IV. In addition, docking studies were performed with compounds $\mathbf{2} \mathbf{a}, \mathbf{b} ; \mathbf{3} \mathbf{3}, \mathbf{b} ; \mathbf{4} \mathbf{a}, \mathbf{b}$ and $\mathbf{5 a}, \mathbf{b}$, to illustrate their binding mode in the active site of DNA gyrase B compared with that of novobiocin. The docking results of the tested compounds were compatible with their inhibitory potency and gave binding scores ranging from -5.25 to $-6.99 \mathrm{kcal} / \mathrm{mol}$.

The results of this study pointed to the importance of pyridothienopyrimidine compounds as a promising heterocyclic sector that, with further study and development, can provide new antimicrobial agents competent of facing the increasing antimicrobial resistance.

Supplementary Materials: The following are available online at http://www.mdpi.com/2079-6382/9/10/695/s1, Figures S1-S28: NMR spectra of compounds $\mathbf{2} \mathbf{a}, \mathbf{b}-\mathbf{8} \mathbf{a}, \mathbf{b}$.

Author Contributions: Conceptualization of work, E.M.M.E.-D.; methodology of synthesis, E.M.M.E.-D., E.A.A.E.-M. and M.F.A.; validation of structures, E.M.M.E.-D. and E.A.A.E.-M.; investigation of antimicrobial aspects, E.A.K.; data curation E.M.M.E.-D. and E.A.A.E.-M.; software docking studies, E.S.N.; writing-original draft, E.M.M.E.-D.; writing-review and editing, E.A.A.E.-M. and M.F.A. All authors have read and agreed to the published version of the manuscript.

Funding: This research received no external funding.

Conflicts of Interest: The authors declare no conflict of interest.

\section{References}

1. Sifri, Z.C.; Chokshi, A.; Cennimo, D.; Horng, H. Global contributors to antibiotic resistance. J. Glob. Infect. Dis. 2019, 11, 36-42. [CrossRef] [PubMed]

2. Lomazzi, M.; Moore, M.; Johnson, A.; Balasegaram, M.; Borisch, B. Antimicrobial resistance-moving forward? BMC Public Health 2019, 19, 858. [CrossRef] [PubMed]

3. De Kraker, M.E.A.; Stewardson, A.J.; Harbarth, S. Will 10 Million People Die a Year due to Antimicrobial Resistance by 2050? PLoS Med. 2016, 13, e1002184. [CrossRef] [PubMed]

4. Gwynn, M.N.; Portnoy, A.; Rittenhouse, S.F.; Payne, D.J. Challenges of antibacterial discovery revisited. Ann. N. Y. Acad. Sci. 2010, 1213, 5-19. [CrossRef]

5. Yi, L.; Lu, X. New Strategy on antimicrobial-resistance: Inhibitors of DNA replication enzymes. Curr. Med. Chem. 2019, 26, 1761-1787. [CrossRef]

6. Klostermeier, D. Why two? On the role of (A-)symmetry in negative supercoiling of DNA by gyrase. Int. J. Mol. Sci. 2018, 19, 1489. [CrossRef] [PubMed]

7. Berger, J.; Schoeffler, A. Recent advances in understanding structure-function relationships in the type II topoisomerase mechanism. Biochem. Soc. Trans. 2005, 33, 1465-1470. [CrossRef] [PubMed]

8. Van Eijk, E.; Wittekoek, B.; Kuijper, E.J.; Smits, W.K. DNA replication proteins as potential targets for antimicrobials in drug-resistant bacterial pathogens. J. Antimicrob. Chemother. 2017, 72, 1275-1284. [CrossRef]

9. Singh, S.B. Confronting the challenges of discovery of novel antibacterial agents. Bioorganic Med. Chem. Lett. 2014, 24, 3683-3689. [CrossRef] [PubMed]

10. Collin, F.; Karkare, S.; Maxwell, A. Exploiting bacterial DNA gyrase as a drug target: Current state and perspectives. Appl. Microbiol. Biotechnol. 2011, 92, 479-497. [CrossRef] 
11. Aldred, K.J.; Kerns, R.J.; Osheroff, N. Mechanism of quinolone action and resistance. Biochemistry 2014, 53, 1565-1574. [CrossRef] [PubMed]

12. Mustaev, A.; Malik, M.; Zhao, X.; Kurepina, N.; Luan, G.; Oppegard, L.M.; Hiasa, H.; Marks, K.R.; Kerns, R.J.; Berger, J.M.; et al. Fluoroquinolone-Gyrase-DNA Complexes. J. Biol. Chem. 2014, 289, 12300-12312. [CrossRef] [PubMed]

13. Kim, E.S.; Hooper, D. Clinical importance and epidemiology of quinolone resistance. Infect. Chemother. 2014, 46, 226-238. [CrossRef] [PubMed]

14. Correia, S.; Poeta, P.; Hébraud, M.; Capelo, J.L.; Igrejas, G. Mechanisms of quinolone action and resistance: Where do we stand? J. Med. Microbiol. 2017, 66, 551-559. [CrossRef]

15. Badshah, S.L.; Ullah, A. New developments in non-quinolone-based antibiotics for the inhibiton of bacterial gyrase and topoisomerase IV. Eur. J. Med. Chem. 2018, 152, 393-400. [CrossRef]

16. Jakopin, Ž.; Ilaš, J.; Barančoková, M.; Brvar, M.; Tammela, P.; Dolenc, M.S.; Tomašič, T.; Kikelj, D. Discovery of substituted oxadiazoles as a novel scaffold for DNA gyrase inhibitors. Eur. J. Med. Chem. 2017, 130, 171-184. [CrossRef]

17. Zidar, N.; Macut, H.; Tomašič, T.; Mašič, L.P.; Ilaš, J.; Zega, A.; Tammela, P.; Kikelj, D. New N-phenyl-4,5-dibromopyrrolamides as DNA gyrase B inhibitors. MedChemComm 2019, 10, 1007-1017. [CrossRef]

18. Kumar, S.; Narasimhan, B. Therapeutic potential of heterocyclic pyrimidine scaffolds. Chem. Central J. 2018, 12, 38. [CrossRef]

19. Hung, J.M.; Arabshahi, H.J.; Leung, E.; Reynisson, J.; Barker, D. Synthesis and cytotoxicity of thieno[2,3-b]pyridine and furo[2,3-b]pyridine derivatives. Eur. J. Med. Chem. 2014, 86, 420-437. [CrossRef]

20. Arabshahi, H.J.; Pilkington, L.I.; Jeon, C.Y.; Song, M.; Gridel, L.-M.; Zakharenko, A.L.; Lavrik, O.I.; Van Rensburg, M.; Leung, E.; Barker, D.; et al. A synthesis, in silico, in vitro and in vivo study of thieno[2,3-b]pyridine anticancer analogues. MedChemComm 2015, 6, 1987-1997. [CrossRef]

21. Naguib, B.H.; El-Nassan, H.B. Synthesis of new thieno[2,3-b]pyridine derivatives as pim-1 inhibitors. J. Enzym. Inhib. Med. Chem. 2016, 31, 1718-1725. [CrossRef]

22. Al-Trawneh, S.A.; El-Abadelah, M.M.; Zahra, J.A.; Al-Taweel, S.A.; Zani, F.; Incerti, M.; Cavazzoni, A.; Vicini, P. Synthesis and biological evaluation of tetracyclic thienopyridones as antibacterial and antitumor agents. Bioorganic Med. Chem. 2011, 19, 2541-2548. [CrossRef] [PubMed]

23. El-Deen, E.M.M.; El-Hameed, E.K.A. Synthesis and in vitro biological evaluation of new tetracyclic pyridothienoquinolines as potential antimicrobial agents. Acta Pol. Pharm. Drug Res. 2017, 74, 837-847.

24. Amorim, R.; De Meneses, M.D.F.; Borges, J.C.; Pinheiro, L.C.S.; Caldas, L.A.; Cirne-Santos, C.C.; De Mello, M.V.; De Souza, A.M.T.; Castro, H.C.; Paixão, I.C.N.D.P.; et al. Thieno[2,3-b]pyridine derivatives: A new class of antiviral drugs against Mayaro virus. Arch. Virol. 2017, 162, 1577-1587. [CrossRef] [PubMed]

25. Schnute, M.E.; Anderson, D.J.; Brideau, R.J.; Ciske, F.L.; Collier, S.A.; Cudahy, M.M.; Eggen, M.; Genin, M.J.; Hopkins, T.A.; Judge, T.M.; et al. 2-Aryl-2-hydroxyethylamine substituted 4-oxo-4,7-dihydrothieno[2,3-b]pyridines as broad-spectrum inhibitors of human herpesvirus polymerases. Bioorganic Med. Chem. Lett. 2007, 17, 3349-3353. [CrossRef] [PubMed]

26. Liu, H.; Li, Y.; Wang, X.-Y.; Wang, B.; He, H.-Y.; Liu, J.-Y.; Xiang, M.-L.; He, J.; Wu, X.-H.; Yang, L. Synthesis, preliminary structure-activity relationships, and in vitro biological evaluation of 6-aryl-3-amino-thieno[2,3-b]pyridine derivatives as potential anti-inflammatory agents. Bioorganic Med. Chem. Lett. 2013, 23, 2349-2352. [CrossRef]

27. Saito, K.; Nakao, A.; Shinozuka, T.; Shimada, K.; Matsui, S.; Oizumi, K.; Yano, K.; Ohata, K.; Nakai, D.; Nagai, Y.; et al. Discovery and structure-activity relationship of thienopyridine derivatives as bone anabolic agents. Bioorganic Med. Chem. 2013, 21, 1628-1642. [CrossRef]

28. Gad-Elkareem, M.A.; Abdel-Fattah, A.M.; Elneairy, M.A.A. Pyridine-2(1 H)-thione in heterocyclic synthesis: Synthesis and antimicrobial activity of some new thio-substituted ethyl nicotinate, thieno[2,3- $b$ ]pyridine and pyridothienopyrimidine derivatives. J. Sulfur Chem. 2011, 32, 273-286. [CrossRef]

29. El-Aleam, R.H.A.; George, R.F.; Hassan, G.S.; Abdel-Rahman, H.M. Synthesis of 1,2,4-triazolo[1,5-a] pyrimidine derivatives: Antimicrobial activity, DNA Gyrase inhibition and molecular docking. Bioorganic Chem. 2020, 94, 103411. [CrossRef]

30. Patil, S.B. Biological and medicinal significance of pyrimidines: A review. Int. J. Pharm Sci. Res. 2018, 9, 44-52. [CrossRef] 
31. Fayed, A.A.; Amr, A.E.-G.E.; Al-Omar, M.A.; Mostafa, E.E. Synthesis and antimicrobial activity of some new substituted pyrido[3',2':4,5]thieno[3,2-d]-pyrimidinone derivatives. Russ. J. Bioorganic Chem. 2014, 40, 308-313. [CrossRef]

32. El-Essawy, F.A.; Boshta, N.M.; El-Sawaf, A.K.; Nassar, A.A.; Khalafallah, M.S. Synthesis of novel 3-substituted pyridothienopyrimidine derivatives with biological evaluation as antimicrobial agents. Chem. Res. Chin. Univ. 2016, 32, 967-972. [CrossRef]

33. Kadah, M.S. Synthesis of some new thienopyridine and pyridothienopyrimidine derivatives with expected antitumor activity. Int. J. Med Sci. 2016, 3, 5-10. [CrossRef]

34. Naguib, B.H.; El-Nassan, H.B.; Abdelghany, T.M. Synthesis of new pyridothienopyrimidinone derivatives as Pim-1 inhibitors. J. Enzym. Inhib. Med. Chem. 2017, 32, 457-467. [CrossRef]

35. El-Nassan, H.B.; Naguib, B.H.; Beshay, E.A. Synthesis of new pyridothienopyrimidinone and pyridothienotriazolopyrimidine derivatives as pim-1 inhibitors. J. Enzym. Inhib. Med. Chem. 2017, 33, 58-66. [CrossRef] [PubMed]

36. Aziz, Y.M.A.; Said, M.M.; El Shihawy, H.A.; Abouzid, K.A. Discovery of novel tricyclic pyrido[3', 2':4,5]thieno[3,2-d]pyrimidin-4-amine derivatives as VEGFR-2 inhibitors. Bioorganic Chem. 2015, 60, 1-12. [CrossRef] [PubMed]

37. El-Deen, E.M.; El-Meguid, E.A.A.; Hasabelnaby, S.; Karam, E.A.; Nossier, E.S.; El-Deen, E.M.; El-Meguid, E.A.A. Synthesis, Docking Studies, and In Vitro Evaluation of Some Novel Thienopyridines and Fused Thienopyridine-Quinolines as Antibacterial Agents and DNA Gyrase Inhibitors. Molecules 2019, 24, 3650. [CrossRef]

38. Tari, L.W.; Trzoss, M.; Bensen, D.C.; Li, X.; Chen, Z.; Lam, T.; Zhang, J.; Creighton, C.J.; Cunningham, M.L.; Kwan, B.; et al. Pyrrolopyrimidine inhibitors of DNA gyrase B (GyrB) and topoisomerase IV (ParE). Part I: Structure guided discovery and optimization of dual targeting agents with potent, broad-spectrum enzymatic activity. Bioorganic Med. Chem. Lett. 2013, 23, 1529-1536. [CrossRef] [PubMed]

39. Trzoss, M.; Bensen, D.C.; Li, X.; Chen, Z.; Lam, T.; Zhang, J.; Creighton, C.J.; Cunningham, M.L.; Kwan, B.; Stidham, M.; et al. Pyrrolopyrimidine inhibitors of DNA gyrase B (GyrB) and topoisomerase IV (ParE), Part II: Development of inhibitors with broad spectrum, Gram-negative antibacterial activity. Bioorganic Med. Chem. Lett. 2013, 23, 1537-1543. [CrossRef]

40. Patel, R.; Park, S. An evolving role of piperazine moieties in drug design and discovery. Mini-Rev. Med. Chem. 2013, 13, 1579-1601. [CrossRef]

41. Patil, P.; Madhavachary, R.; Kurpiewska, K.; Kalinowska-Tłuścik, J.; Dömling, A. De Novo assembly of highly substituted morpholines and piperazines. Org. Lett. 2017, 19, 642-645. [CrossRef] [PubMed]

42. Popiołek, Ł. Hydrazide-hydrazones as potential antimicrobial agents: Overview of the literature since 2010. Med. Chem. Res. 2016, 26, 287-301. [CrossRef]

43. Rollas, S.; Küçükgüzel, S.G. Biological activities of hydrazone derivatives. Molecules 2007, 12, $1910-1939$. [CrossRef] [PubMed]

44. Michael, J.M.; El-Zahar, M.I.; El-Masry, A.M.; Mohi El-Deen, E.M. New pyrido [3,2:4,5] thieno [3,2-D] pyrimidines of possible antimicrobial activity. Al-Azhar Bull. Sci. 1992, 3, 767.

45. Sharanin, Y.A.; Motrosova, S.V. Cyclization Reaction of Nitriles Part 56. Synthesis and transformations of substituted 6-aryl-4-(2-thienyl)-3-cyano-pyridine-2(1h)-thiones. Zh. Org. Khim. 1996, 32, 1251-1255.

46. Elzahabi, H.S.A.; Nossier, E.S.; Khalifa, N.M.; AlAsfoury, R.A.; El-Manawaty, M.A. Anticancer evaluation and molecular modeling of multi-targeted kinase inhibitors based pyrido[2,3-d]pyrimidine scaffold. J. Enzym. Inhib. Med. Chem. 2018, 33, 546-557. [CrossRef]

47. Holdgate, G.A.; Tunnicliffe, A.; Ward, W.H.J.; Weston, S.A.; Rosenbrock, G.; Barth, P.T.; Taylor, I.W.F.; Pauptit, R.A.; Timms, D. The entropic penalty of ordered water accounts for weaker binding of the antibiotic novobiocin to a resistant mutant of DNA gyrase: A thermodynamic and crystallographic study. Biochem. 1997, 36, 9663-9673. [CrossRef] [PubMed]

48. Wiegand, I.; Hilpert, K.; Hancock, R.E.W. Agar and broth dilution methods to determine the minimal inhibitory concentration (MIC) of antimicrobial substances. Nat. Protoc. 2008, 3, 163-175. [CrossRef]

49. Phillips, J.W.; Goetz, M.A.; Smith, S.K.; Zink, D.L.; Polishook, J.; Onishi, R.; Salowe, S.; Wiltsie, J.; Allocco, J.; Sigmund, J.; et al. Discovery of Kibdelomycin, A Potent new class of bacterial type II topoisomerase inhibitor by chemical-genetic profiling in staphylococcus aureus. Chem. Biol. 2011, 18, 955-965. [CrossRef] [PubMed] 
50. Maxwell, A.; Burton, N.P.; O'Hagan, N. High-throughput assays for DNA gyrase and other topoisomerases. Nucleic Acids Res. 2006, 34, e104. [CrossRef]

51. Bellon, S.; Parsons, J.D.; Wei, Y.; Hayakawa, K.; Swenson, L.L.; Charifson, P.S.; Lippke, J.A.; Aldape, R.; Gross, C.H. Crystal structures of escherichia coli topoisomerase IV pare subunit (24 and 43 Kilodaltons): A single residue dictates differences in novobiocin potency against topoisomerase IV and DNA gyrase. Antimicrob. Agents Chemother. 2004, 48, 1856-1864. [CrossRef] [PubMed]

Publisher's Note: MDPI stays neutral with regard to jurisdictional claims in published maps and institutional affiliations.

(C) 2020 by the authors. Licensee MDPI, Basel, Switzerland. This article is an open access article distributed under the terms and conditions of the Creative Commons Attribution (CC BY) license (http://creativecommons.org/licenses/by/4.0/). 